\title{
THE GDL MARSHALS' INSIGNIA AND THEIR PLACE IN CEREMONIAL BETWEEN THE SIXTEENTH AND EIGHTEENTH CENTURIES
}

\author{
Gitana Zujiené
}

ABSTRACT This paper examines the origin, development, appearance and functions of the baton of the marshal, one of the highest officials of the Lithuanian Grand Duchy between the sixteenth and eighteenth centuries. Attention is also paid to the ceremony of its conferment and solemn speeches delivered on that occasion. The marshal's baton was not merely a piece of insignia symbolising the authority and power of the official in performing his duties, and it was not only shown in his portraits, coats of arms and seals or during his funeral, but it was also a means of carrying out his duties. From this point of view the baton had three main functions. Borne before the ruler, it symbolised the respect shown to him. By beating his baton on the floor the marshal regulated the proceedings of the sessions of the sejm and audiences, gave the floor to the speaker or quietened noise-makers. Finally, the baton could be used as an ordinary staff to make way in the crowd or to discipline the rowdy ones. To reveal the functions of the baton, the marshal's duties in the election, coronation, and burial of the sovereign, in the ceremonials of the court, the reception of envoys and in other public occasions are discussed.

The office of marshal was one of the highest and oldest posts in the state. It is believed to have derived from Germany. The word 'marshal' is derived from the Germanic compound * markhaskalkaz, consisting of markhas 'horse' and skalkaz 'servant'. Originally the word meant 'keeper/master of the horse' and later 'an official in charge of the cavalry'. In the fourteenth century the office and the term entered Poland from Germany via Bohemia and having lost its previous sense it meant a high official in the household of a king or duke. ${ }^{1}$

${ }^{1}$ R. Petrauskas, 'Ponas savo žemėje: Lietuvos pareigūnai XIV a. pradžioje XV amžiuje', Lietuvos istorijos metraštis, no. 1, 2001 (Vilnius, 2002), p. 11. 
In GDL sources the court marshal (marschalcus curie nostre) was mentioned for the first time in a letter of the grand duke Vytautas in $1395 .^{2}$ In another of his letters dated 1407 the same official is referred to as the land marshal (marschalcus terre Lithuanie). ${ }^{3}$ At the end of Vytautas' reign these two posts finally became differentiated, though officially the office of court marshal was established by Grand Duke Alexander only in about $1494 .{ }^{4}$ From the sixteenth century land marshals were called high and from the seventeenth century grand marshals. ${ }^{5}$

Lithuanian historians consider that this office appeared independently in the country, and only the term for it was borrowed. ${ }^{6}$

In Poland the functions of marshals were codified in $1504 .^{7}$ There are no data about corresponding initiatives in the GDL. Therefore it is presumed that in Lithuania, ruled by the same sovereign, the functions of marshals must have been similar. ${ }^{8}$ They can be divided into three principal groups. Firstly, the marshals were entrusted with keeping order and security at court. Secondly, they participated in the political life of the state, they were members of the Council of Lords and after the Union of Lublin members of the joint senate. Thirdly, they were responsible for the conduct of ceremonials. The present paper is devoted namely to this third function since the baton, its origin, presentation and use are inseparably linked to the ceremonial.

Previous scholarship For Lithuanian historians this topic is a novelty. Admittedly, currently a certain interest in the court and

${ }^{2}$ Vitoldiana, ed. J. Ochmański (Warsaw-Poznań, 1986), no. 13.

${ }^{3}$ Ibid., no. 70.

${ }^{4}$ J. Wolff, Senatorowie i dygnitarze Wielkiego Księstwa Litewskiego 1386 1795 (Cracow, 1885), pp. 166, 178.

${ }^{5}$ Urzędnicy centralni $i$ dostojnicy Wielkiego Księstwa Litewskiego XIVXVIII wieku, ed. H. Lulewicz, A. Rachuba (Kórnik, 1994), p. 71.

${ }^{6}$ E. Gudavičius, Lietuvos istorija, vol. 1 (Vilnius, 1999), p. 400. Meanwhile opinions of Polish historians vary. Z. Góralski, most probably basing himself on the Polish authors of the eighteenth century W. Skrzetuski, K. Niesiecki and B. Lengnich, argues that this office was established following the Polish example by the grand duke of Lithuania Jogaila, who also became king of Poland in 1386. W. Kamieniecki and L. Korczak are of the opinion that Vytautas adopted this office from the Teutonic Order.

${ }^{7}$ Volumina Legum (hereafter VL), vol. 1 (St Petersburg, 1859), p. 135.

${ }^{8}$ L. Korczak, 'Marszałkowie ziemscy w Wielkim Księstwie Litewskim w XV wieku', Cracovia - Polonia - Europa, ed. K. Baczkowski et al. (Cracow, 1995), p. 375 . 
political ceremonials in the GDL is evident. A number of articles by Lithuanian authors as well as some translations were devoted namely to this issue. ${ }^{9}$ Several articles on the everyday life of the sovereign's court have also appeared, in which, among other things, ceremonial has been dealt with briefly. ${ }^{10}$ However, speaking about the functions of various officials, these authors do not examine their insignia and their role in the ceremonial. A short article devoted specifically to the marshal's insignia is to be found only in Lietuviu enciklopedija, published in Boston, Massachusets. ${ }^{11}$

This topic has been dealt with at some length by Polish historians. The first illustration of a Polish marshal's baton, accompanied by a description and an attempt to determine its ownership, was published in the middle of the nineteenth century. ${ }^{12}$ Later interest in royal regalia and the ceremonies of their presentation predominated for a long time. Whenever historians undertook a task of researching the insignia of officials, they usually confined themselves to military symbols, the insignia of hetmans. ${ }^{13}$ Attention to the marshal's

${ }^{9}$ M. Sirutavičius, 'Diplomatinis ceremonialas Lietuvos Didžiosios Kunigaikštystès ir Maskvos santykiu praktikoje (XV-XVI a. sandūroje)', Lietuvos istorijos metraštis (hereafter LIM), vol. 1, 2003 (Vilnius, 2004), pp. 81-102; A. Bues, 'Politinè ceremonialo paskirtis elekcinejje monarchijoje: Lenkija-Lietuva XVI-XVIII a.', LIM, vol. 2, 2003 (Vilnius, 2005), pp. 5-20.

${ }^{10}$ R. Čapaite, 'Lietuvos didžiojo kunigaikščio Vytauto kasdienybė pagal jo ir jo amžininkų korespondenciją', Alytaus miesto istorijos fragmentai (Alytus, 2001), pp. 10-27; ead., 'The Everyday Life of Grand Duke Vytautas of Lithuania according to his Correspondence and that of his Contemporaries', Lithuanian Historical Studies, vol. 8 (Vilnius, 2004), pp. 1-26; R. Petrauskas, 'Vytauto dvaras: struktūra ir kasdienybė', Naujasis židinys, vol. 1-2 (2003), pp. 39-44; S.C. Rowell, 'Trumpos akimirkos iš Kazimiero Jogailaičio dvaro: neeilinè kasdienybè tarnauja valstybei', $L I M$, vol. 1 (Vilnius, 2005), pp. 25-56.

11 A. Šapoka, 'Maršalkos lazda', Lietuviu enciklopedija, vol. 17 (Boston, 1958), p. 408.

In 2005 the author of this article defended her doctoral thesis at the Lithuanian Institute of History Lietuvos Didžiosios Kunigaikštystès valdovu, aukščiausiu valstybès ir bažnyčios dignitoriu insignijos ir ceremonialas viešajame gyvenime XIII-XVIII $a$., which contains a chapter on the insignia of marshals and the place of these officials in the ceremonial. The work is to be found in the library of the Institute and in the Manuscript Department of the National Martynas Mažvydas Library, Vilnius; currently a book is being prepared for publication.

${ }^{12}$ A. Przezdziecki, E. Rastawiecki, Wzory sztuki średniowiecznej w dawnej Polsce, ser. 1, book 2, table Rr (Warsaw-Paris, 1835-1855).

${ }^{13}$ B. Starzyński, Broń zaczepna i odporna w Polsce, manuscript in Biblioteka Jagiellońska, Cracow, 7003 III; Z. Źygulski, 'Geneza i typologia buław hetmańskich', Muzealnictwo wojskowe, vol. 2 (1964), pp 239-288; idem, Broń w dawnej Polsce (Warsaw, 1982); idem, Stara broń w polskich zbiorach (Warsaw, 1982). 
insignia was renewed by a follower of the German historian Percy Ernst Schramm, Witold Maisel, who became interested in Schramm's research in legal archaeology, one aspect of which was symbols of authority. ${ }^{14}$ He briefly described the appearance of marshal batons, some of their functions and mentioned a GDL marshal's baton, kept in the Kórnik Library, Poland. In his work on Polish offices, Z. Góralski published a picture of the baton of Juozapas Scipionas, a marshal of the GDL. ${ }^{15}$ An illustration of the bindings of the same baton was also published by J.A. Gierowski. ${ }^{16}$ The baton of a Polish marshal, used by him in the sejm in 1830-1831, was analysed by J.K. Ostrowski; he also presented a concise review of the use of marshal batons before the partitions of Poland-Lithuania. ${ }^{17}$ The most comprehensive study of marshal insignia of Poland and Lithuania was made by J. Lileyko. In his book on the Sejm of Poland examining the insignia and attributes of its officials, he tried to determine when the batons came to be used and discussed their appearance and functions in the ceremonial of the sejm. ${ }^{18}$

Sometimes particular functions of marshal batons were discussed in passing in the investigations of the way of life, ${ }^{19}$ even in the studies of funeral ceremonies. ${ }^{20}$

Western European scholarship abounds in works that analyse the baton as a symbol and insignia of a sovereign or official; however, the batons of the marshals of the Commonwealth are not mentioned there. ${ }^{21}$

${ }^{14}$ V. Maisel, Archeologia prawna Polski (Warsaw-Poznań, 1982), pp. 235 236); idem, Archeologia prawna Europy (Warsaw-Poznań, 1989), pp. 270-276.

${ }^{15}$ Z. Góralski, Urzędy i godności w dawnej Polsce (Warsaw, 1983), table 7.

16 J.A. Gierowski, Rzeczpospolita $w$ dobie złotej wolności (1648-1763), Wielka historia Polski, vol. 5 (Cracow, 2001), p. 272.

17 J.K. Ostrowski, 'O lasce marszalka sejmu z lat 1830-1831', Curia maior. Studia z dziejów kultury ofiarowane A. Ciechanowskiemu (Warsaw, 1990), pp. 181-187.

18 J. Lileyko, Sejm polski. Tradycja-ikonografia-sztuka (Warsaw, 2003), pp. 107-114.

${ }^{19}$ W. Loziński, Życie polskie w dawnych wiekach (Lvov, 1907); W. Czapliński, J. Długosz, Życie codzienne magnaterii polskiej w XVII w. (Warsaw, 1976); J.S. Bystron, Dzieje obyczajów w dawnej Polsce. Wiek XVI-XVIII, vol. 1-2 (Warsaw, 1976); M. Bogucka, Staropolskie obyczaje w XVI-XVII wieku (Warsaw, 1994).

${ }^{20}$ J. Chrościcki, „Pompa funebris “ (Warsaw, 1974); A. Novicka-Jeżowa, Sarmaci i śmierć (Warsaw, 1992).

${ }^{21}$ K. Amira, Der Stab in der germanischen Rechtssymbolik (Munich, 1909); L. Carlen, 'Stab und Stabträger in der Schweiz. Zur Rechts- und Staatssymbolik des Stabes', Festschrift Nikolaus Grass (Innsbruck, 1974-1975); F. Focke, 'Szepter und Krummstab. Eine symbolgeschichtliche Untersuchung', Festgabe für Alois Fuch (Paderborn, 1950); G. Kocher, Richter und Stabübergabe im Verfahren der Weistümer (Graz, 1971). 
Sources The sources used in this work fall into several groups. The first group comprises extant batons of the GDL marshals. One of them, held in the Jagiellonian University Museum, Cracow, belonged to Lithuanian Court Marshal Scipionas. The ownership of the other baton, kept in the Kórnik Library, has not been established. Relying on the fact that the baton shows the Vytis - a mounted knight, Maisel attributed it to Adam Kazimierz Czartoryski, who had the same symbol in his seal. ${ }^{22}$ However, Czartoryski had never been either a court or grand marshal. It should be noted that the Vytis was used in the coat of arms by the Sanguškas, too. In the Saxon period (16971763) even four members of this family held the posts of the GDL marshals. Between 1702 and 1706 the court marshal was Kazimieras Antanas Sanguška. ${ }^{23}$ Povilas Karolis Sanguška was the court marshal between 1713 and 1734, and between 1734 and 1750 he was the grand marshal. ${ }^{24}$ Jonušas Aleksandras Sanguška held the post of court marshal between 1750 and 1760, ${ }^{25}$ and Juozapas Paulinas Sanguška was court marshal between 1760 and 1768. ${ }^{26}$ Therefore, the baton with the Vytis could belong to one of these persons. Iconographic material could help establish the owner; however, the only known Sanguška portrait is that of Povilas Karolis Sanguška, and his portrait shows his baton with both ends encased. The encasements are decorated with vertical rows of precious stones, and there are no signs of any heraldic symbols. ${ }^{27}$

In the National Museum of Lithuania there is one more baton, which is presented as a seventeenth-century marshal baton. ${ }^{28} \mathrm{How}-$ ever, judging from its appearance this baton is unlike those of the Polish or Lithuanian marshals of the seventeenth-eighteenth centuries and could hardly be treated as belonging to a marshal. Consequently, its function might have been different.

The second group of sources consists of written records. Noteworthy are the writings of the middle and second half of the eighteenth century, which deal with the law and political structure of the Polish-

${ }^{22}$ Maisel, Archeologia prawna Polski, p. 235.

23 Urzędnicy, p. 79.

${ }^{24}$ Ibid. pp. 75, 79.

25 Ibid., p. 79.

${ }^{26}$ Ibid., pp. 75, 79 .

${ }^{27}$ The portrait is held at the National Museum of Warsaw. It is published in R.S. Pilsztynowa, Proceder podróźy $i$ życia mego awantur (Cracow, 1957).

${ }^{28}$ XVI-XX a. I p. auksakaliu dirbiniai. Comp. O. Mažeikienè (Vilnius, $1982)$, p. 8 . The inventory number of the baton is IM 8458 . 
Lithuanian Commonwealth. ${ }^{29}$ In these works much attention is given to the competence and order of granting the office of officials.

One more source is the descriptions of ceremonials. Often the marshals themselves collected such descriptions so as to be familiar with the organisation of particular ceremonies. Several of such books have been preserved. ${ }^{30}$ Their compilers were Polish marshals, nevertheless there is no denying that Lithuanian marshals could also have similar collections of the descriptions of ceremonials. These descriptions are a mine of information on the functions of marshals in the organisation of a particular ceremony and the use of insignia in them. Diplomatic ceremonial and the functions of marshals of an earlier period - the late fifteenth and the sixteenth centuries - are well reflected in the instructions to and accounts of envoys of the Grand Duchy of Muscovy and the GDL. ${ }^{31}$ The division of competence between Polish and Lithuanian marshals after the Union of Lublin (1569) was regulated by the rulers' decrees and sejm constitutions. ${ }^{32}$ Reminiscences ${ }^{33}$ and

${ }^{29}$ G.P. Schultz, Commentarius de mareschalcis Regni Poloniae cum duplici mantissa de mareschalcis et cancellariis Magnus Ducatus Lithuaniae (Gdańsk, 1743); W. Skrzetuski, Prawo polityczne narodu polskiego, vol. 1-2 (Warsaw, 17821784); B. Lengnich, Prawo pospolite Królestwa Polskiego (Cracow, 1836).

${ }^{30}$ Ceremonial na przymowaniu y audiencyach poslów postronnych $w$ Królestwe Polskim praktykowany, Biblioteka PAN i PAU in Cracow, mss. 334, 335 (the collections are ascribed to the Polish marshals Józef Wandalin (1713-1742) and Jerzy August (1742-1767) Mniszechs); Akta ceremonialów publizcnych, tudziesz rożnich okoliczności krajowych y zagranicznych do urzędu marszalkowskiego należacych, zebrane za laski JO Xcia Jmci Stanisława Lubomirskiego, marszalka wielkiego koronnego, AGAD, Archiw Zamoyskich (AZ), mss. 3061 (collection compiled by the grand marshal Stanisław Lubomirski of Poland (1766-1783)).

31 Sbornik imperatorskogo russkogo obshchestva, vol. 35 (1487-1533) (St Petersburg, 1882); vol. 59 (1533-1560) (St Petersburg, 1889); vol. 71 (15601571) (St Petersburg, 1892).

${ }^{32}$ VL, vols. 1-9, 10 (St Petersburg, 1859-1860, 1889); Akta unji Polski z Litwa 1385-1795, ed. S. Kutrzeba, W. Semkowicz (Cracow, 1932).

${ }^{33}$ Pamiętniki pana de Beaujeu 1679-1692, Cudzoziemcy o Polsce. Relacje i opinie, ed. J. Gintel, vol. 1 (Cracow, 1971); Kronika Pawla Piaseckiego, biskupa Przemyślskiego (Cracow, 1870); O elekcyi Heryka Walezyusza na króla polskiego. Pamiętniki Jana Szoane (Jean Choisnin) sekretarza Maluka biskupa Walencyi i radzcy tayney rady królewskiey XVI wieku, comp. W. Turski (Vilnius, 1818); M. Vorbek-Lettow, Skarbnica pamięci. Pamiętnik lekarza króla Władysława $I V$, ed. E. Galos, F. Mincer (Wroclaw-Warsaw-Cracow, 1986); Pamiętniki do panowania Zygmunta III, Władysława IV i Jana Kazimierza, comp. K.W. Wóycicki (Warsaw, 1846); A.S. Radzwiłł, Memoriale rerum gestarum in Polonia, ed. A. Przyboś, R. Źelewski (Wroclaw-Warsaw-Cracow, 1968); K. Sarnecki, Pamiętniki z czasów Jana Sobieskiego, ed. J. Woliński (Wroclaw, 1958). 
diaries $^{34}$ of contemporaries, sejm accounts, ${ }^{35}$ accounts of foreign envoys, ${ }^{36}$ descriptions of the funerals of sovereigns and officials ${ }^{37}$ are worth noting, too. There are also speeches delivered at the sejm on the occasions of granting the office of marshal ${ }^{38}$ or burying an official. $^{39}$ These sources contain extensive data on the ceremony of granting the insignia and its use. They also show how the insignia were treated by the citizens of the GDL and foreign guests. This sort of information can also be found in the eighteenth-century descriptions of the way of life. ${ }^{40}$

Iconographic materials make up the third group for sources. In the first place representative portraits of marshals should be mentioned - according to contemporary tradition they had to be shown with their insignia. The earliest portrait of a GDL marshal goes back to the first half of the seventeenth century. It shows Mikalojus

${ }^{34}$ Dyariusz wojewody witebskiego Jana Antonego Chrapowickiego, ed. I. Rusecki (Warsaw, 1845); A. Krutta, Dziennik przyjęcia i pobytu nadzwyczajnego posta Porty Ottomańskiej do Stanistawa Augusta 1777 r. (Warsaw, 1860); M. Radoszewski, Diariusz koronacyjej najjaśniejszego Władysława Zygmunta IV (Opole, 2002).

35 Warszawski sejm 1563-1564, Źródłopisma do dziejów unii Korony Polskiej i W.X. Litewskiego, ed. A.T. Działyński (Poznań, 1868); Dnevnik Liublinskogo sejma 1569 goda (S. Peterburg, 1869); Dyariusze sejmowe z wieku XVIII, ed. W. Konopczyński, vols. 1-3 (Warsaw, 1911-1912).

${ }^{36}$ Relacye nuncyuszów apostolskich i innych osób o Polsce od roku 1548 do 1690, comp. E. Rykaczewski, vols. 1-2 (Berlin-Poznań, 1864); Cudzoziemcy o Polsce ..., vols. 1-2 (Cracow, 1971); Dyplomacy $w$ dawnych czasach. Relacje staropolskie z XVI-XVIII stulecia, ed. A. Przyboś, R. Źelewski (Cracow, 1959); Polska stanisławowska $w$ aczach cudzoziemców, ed. W. Zawadski (Warsaw, 1963).

37 Relacya pogrzebowa ... Pawla Karola Sanguszka ..., 1751; Relacya pogrzebu serca xiażacego Pawla Karola Sanguszka ... marszalka wielkiego $W X L, 1751$.

${ }^{38}$ Swada polska y tacinska albo miscellanea oratorskie seymowe, weselne, kancellaryine, listowe, kaznodzieyskie, pogrzebowe, statystyczne, panegyriczne, elogiarne, inskrypcyine y inne różne $w$ oboim jęziku prozq $i$ wierszem przez Jana Ostrowskiego Daneykowicza jego Kr. Mci Sekretarza zebrane ... w Lublinie, cz. 1, 1745.

${ }^{39}$ Laska marszałkowska na pogrzebie Jaśnie Wielmożnego pana MCI P. Jana Stanistawa Sapiehi Marszatka wielkiego W. X. L. ... przez Macieja Kazimierza Sarbiewskiego ..., Wilno, 21 lipca 1633; K. Glinojecki, Rozmiar trojali laski marszatkowskej jaśnie wielmożnego iego mosci P. Alexandra Hilarego Potubinskiego Marszatka W. X. L. 16 stycznia 1680.

40 J. Kitowicz, Opis obyczajów za panowania Augusta III, ed. R. Pollak (Wrocław-Warsaw-Cracow, 1970); J.U. Niemciewicz, Zbiór pamiętników o dawnej Polsce, vol. 1-5 (Leipzig, 1838-1840). 


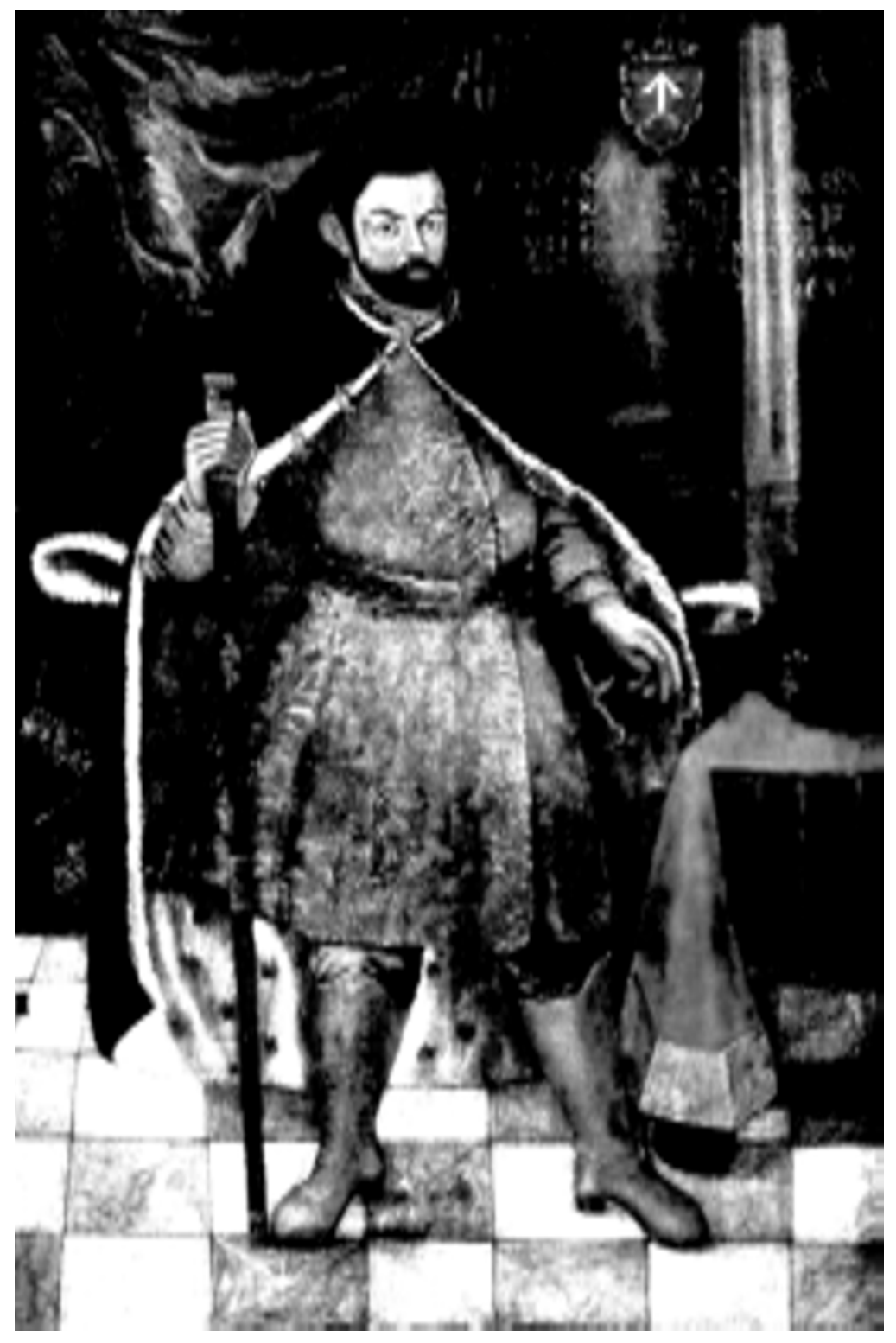

Fig. 1. Court Marshal of the GDL Kristupas Vesiolovskis, 1636. M. Matušakaitè. Portretas XVI-XVIII a. Lietuvoje (Vilnius, 1984). 
Fig. 2 Specimen of the Marshal Coat of Arms in J.A. Jablonowski, Heraldyka, 1752.

J.S. Bystron, Dzieje obyczajów w dawnej Polsce, vol. 2 (Warsaw, 1976).

The original is kept in the Czartoryski Collection, Cracow.

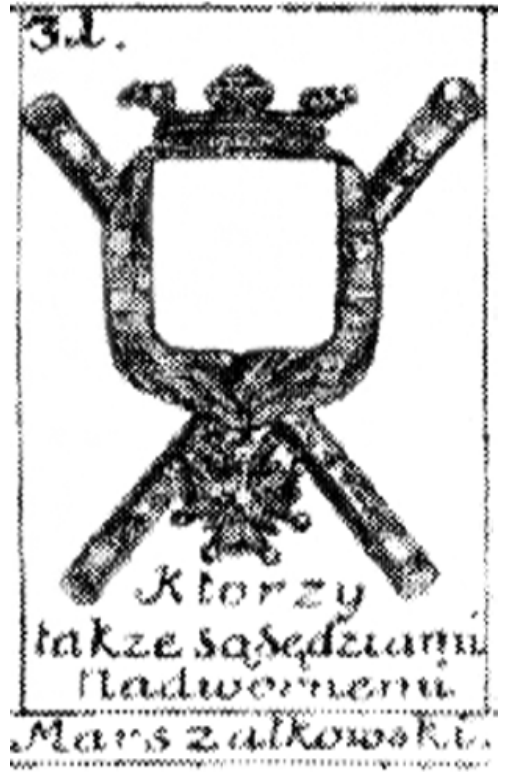

Šimkevičius, the marshal of the Grand Duchy between 1550 and 1563. ${ }^{41}$ The other known portraits of marshals (see Fig. 1) are those of Kristupas Viesiolovskis $(1625-1635,1635-1637),{ }^{42}$ Aleksandras Liudvikas Radvila (1653-1637, 1637-1654), ${ }^{43}$ Kristupas Zaviša (1649-1654, 1654-1669), ${ }^{44}$ P.K. Sanguška (1713-1734, 17341750), ${ }^{45}$ Ignotas Zaviša (1736-1738), ${ }^{46}$ and Vladislovas Gurovskis (1768-1781, 1781-1790). ${ }^{47}$ No less important are pictures, showing various celebrations (the sovereign's entrance into the city, religious festivals, etc.). Being not numerous, they nevertheless reveal the functions of the insignia in the ceremonials. Besides, abstract images of insignia can be found in the illustrations of books and occasional literature; noblemen are shown with insignia in their genealogical trees.

${ }^{41}$ The portrait is held at the National Mikalojus Konstantinas Čiurlionis Art Museum, Kaunas.

${ }^{42}$ The portrait is held at the Belarusian State Museum of Art, Minsk.

${ }^{43}$ The portrait was in the Nesvyžius Gallery; published in B. Taurogiński, Z dziejów Niesvieża (Warsaw, 1937), p. 49.

${ }^{44}$ The portrait is held at the National Mikalojus Konstantinas Čiurlionis Art Museum, Kaunas.

45 The portrait is kept at the National Museum of Poland, Warsaw.

46 The portrait is held at the Belarusian State Museum of Art, Minsk.

47 The portrait is kept at the National Museum of Poland, Poznan. 


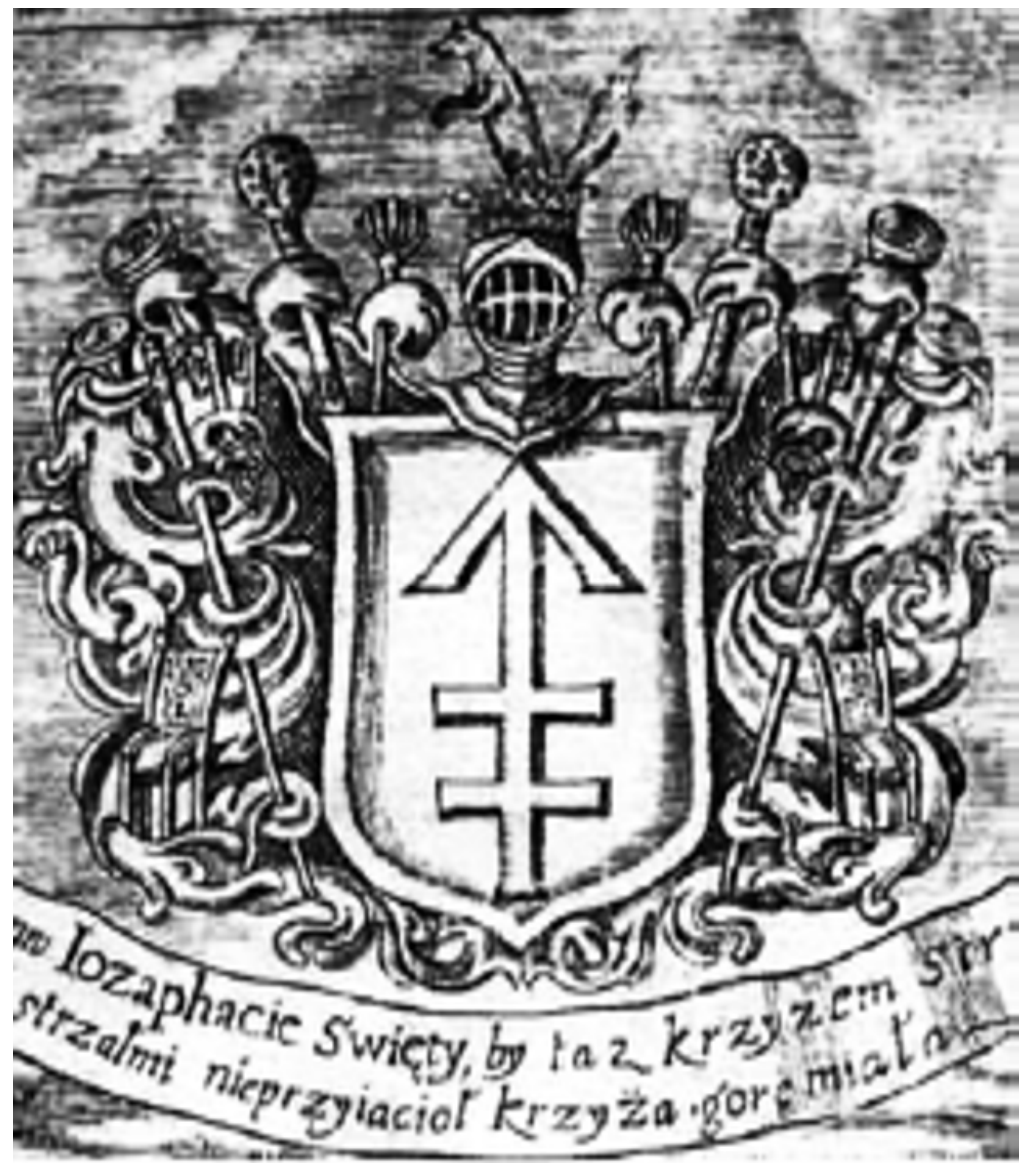

Fig. 3. Sapiegas' Coat of Arms with Marshal Batons in the Folds, 1688. J. Liškevičienè, XVI-XVIII a. knygu grafika. Herbai senuosiuose Lietuvos spausdiniuose (Vilnius, 1998). 
The fourth group comprises heraldic and sphragistic data, because officials had the right to display their insignia in their coats of arms and seals. That was a particularly favourite custom with hetmans and treasurers. In his book Heraldyka, issued in 1752, J.A. Jabłonowski presented specimens of the coats of arms of various officials. ${ }^{48}$ The marshal's arms were shown with two crossed batons behind the escutcheon (Fig. 2). In the GDL sources their batons were shown crossed not only behind the shield, but also in the folds of the mantling (Fig. 3). ${ }^{49}$

Decorations of tombstones ${ }^{50}$ of officials and of some buildings (halls, ${ }^{51}$ castrum doloris ${ }^{52}$ ), etc., containing heraldic elements, can also be seen as a separate group of sources.

The Marshals' Batons As a symbol of authority the baton has been known since antiquity. In ancient Greece it was a sign of the messenger's immunity. ${ }^{53}$ In Rome it was the consuls' symbol of office, and in the Middle Ages it became a symbol of justice. At the same time Western European rulers used the baton as one of their symbols of authority. Between the thirteenth and fourteenth centuries it was gradually replaced by another symbol - the sceptre which also developed from the same shepherd's staff, used by nomadic tribes of the Near East. As symbols of authority batons of diverse shapes were used in Europe by various officials - chieftains, judges, mayors, clergymen, etc.

Persons in charge of ceremonials used the baton as their symbol of office both in Western Europe and in the East. According to Polish historians the baton could appear as an insignia of the Polish marshals early in the sixteenth century. ${ }^{54}$ It is not known precisely when the staff became an insignia of the Lithuanian marshals. In the fifteenth century the grand duke of Lithuania was

${ }^{48}$ These specimens are published in J.S. Bystron, Dzieje obyczajów, vol. 2, pp. 308-309. The book itself is kept in the Czartoryski Collection, Cracow.

${ }^{49}$ The 1688 arms of the Sapiegas. Published in J. Liškevičiene, XVI-XVIII a. knygu grafika. Herbai senuosiuose Lietuvos spausdiniuose (Vilnius, 1998).

50 The sarcophagus of Aleksandras Povilas Sapiega, grand marshal of the GDL (1713-1734). The monument did not survive in the Trinitarian Church, Vilnius; its lithograph was published in V. Drèma, Dingęs Vilnius (Vilnius, 1991).

${ }^{51}$ The Hall of Sejm Sessions in the Royal Castle, Warsaw.

${ }^{52}$ The description of the castrum doloris and of the whole church can be found in the accounts of the funerals of officials.

${ }^{53}$ D. Forster, Świat symboliki chrześcijańskiej (Warsaw, 1990), p. 413.

${ }^{54}$ Lileyko, Sejm polski, p. 107. 
preceded in the procession by the trumpeters rather than by marshals with batons. ${ }^{55}$ Marshals' batons weare mentioned in the descriptions of the funerals of Sigismund the Old and Sigismund August. ${ }^{56}$ However, it seems that these funerals were attended only by Polish marshals. Neither are Lithuanian marshals' batons referred to in the accounts of the Muscovian envoys in the late fifteenth and in the middle of the sixteenth centuries - these diplomats paid exceptional attention in describing the audiences and other ceremonies which they witnessed. ${ }^{57}$ The marshal's baton as a synonym for his office was mentioned in the sejm diaries only in the $1560 \mathrm{~s}$, negotiating the preservation of particular offices in the formation of the union between Poland and Lithuania. ${ }^{58}$ For the first time the GDL marshals were shown with the batons in their portraits only in the first half of the seventeenth century. ${ }^{59}$ Before that time there is no adequate evidence that the marshal's baton was an insignia of the GDL marshals. This custom was taken over most probably from Polish marshals in the process of unifying the state structures on the eve of the union. In Poland the baton could be used originally for a purely practical purpose - to maintain order, and later it acquired the characteristics of a piece of insignia. As a symbol of justice it expressed the function of the marshal judge. ${ }^{60}$ In the seventeenthcentury occasional literature the origin of the baton is associated with the ruler's sceptre. It was argued that the marshals, taking care of the law and order in their estates, performed a part of the duties previously assigned to the sovereign, and consequently the baton as a symbol of their authority was a kind of fraction of the royal sceptre. ${ }^{61}$

55 'Venecijos ambasadoriaus Ambrozijo Kontarinio lankymasis Lietuvoje 1474 ir 1477 metais', transl. E. Ulčinaite, Kraštas ir žmonès. Lietuvos geografiniai ir etnografiniai aprašymai (XIV-XIX a.), ed. J. Jurginis, A. Šidlauskas (Vilnius, 1988), p. 55.

${ }^{56}$ J. Goląb, 'Śmierć i pogrzeb króla polskiego Zygmunta I', Sprawozdanie Dyrekcyi C. K. II wyższej szkoty realnej w Krakowie, vol. 12 (Cracow, 1916), p. 39; Niemciewicz, Zbiór pamiętników, vol. 1, p. 121.

${ }^{57}$ Sbornik, vol. 35, nos. 51, 76, 1882; vol. 71, p. 19, 1892.

${ }^{58}$ Warszawski sejm 1563-1564, p. 272; Dnevnik Liublinskogo seima 1569 goda, pp. 443, 447.

${ }^{59}$ Mikalojus Šimkevičius, the marshal of the Grand Duchy of Lithuania (15501563), is depicted with a baton in his portrait of the late sixteenth - early seventeenth centuries. Earlier portraits are not to be found.

${ }^{60}$ The marshal had its own court and could put offenders on trial on his estate.

${ }^{61}$ Laska marszalkowska na pogrzebie Jaśnie Wielmożnego pana Iego P. Jana Stanisława Sapiehi Marszatka wielkiego W. X. L. ... przez Macieia Kazimierza Sarbiewskiego ..., Wilno, 21 lipca 1635; K. Glinojecki, Rozmiar 
This statement is supported by the present-day Polish historian J.K. Ostrowski. ${ }^{62}$ The shape, décor and some functions of the baton, doubtless, developed in Poland-Lithuania proper. In Z. Żygulski's opinion batons were made by local guilds or goldsmiths of the court. ${ }^{63}$

Queen Maria Kazimierza's secretary, de Beaujeu, wrote in his memoirs that the marshals used to have two types of batons. ${ }^{64}$ The batons, made of white wood, were used in the sejm. That is attested by iconographical materials. In his 1667 portrait Kazimieras Leonas Sapiega is shown with an ordinary wooden baton; he was a marshal of the Warsaw sejm in 1637 and the court marshal of the GDL between 1637 and 1645. ${ }^{65}$ The GDL marshal A.P. Sapiega is depicted with a similar baton on his tombstone. Such batons were used by the sejm marshals, too. They were very long, nearly of human height. Continually knocking to the floor, the marshal could make use of several batons in a week.

Luxurious batons, shown in representative portraits, were used during celebrations, processions, and receptions of foreign envoys. They were made of ebony, their both ends (and often the middle) were sheathed in gold or silver and precious stones. ${ }^{66}$ These decorations contained the coats of arms of the state, the sovereign or the marshal, the monograms of the ruler and the royal insignia. Such a baton could cost up to 50,000 francs. ${ }^{67}$ A baton of this kind belonged to the court marshal of the GDL Scipionas. It was made of ebony, without ribs, slightly tapering off towards the lower end. The ends and the middle of the baton were embellished with precious metals. The monogram of the ruler of Poland-Lithuania August III was engraved at the top end; it also depicted the coat of arms of the Commonwealth of the Two Nations surmounted by the royal crown - the Polish eagle in the first and fourth fields, the

troiaki laski marszalkowskiej jaśnie wielmożnego iego mosci P. Alexandra Hilarego Polubinskiego Marszatka W. X. L. 16 stycznia 1680.

${ }^{62}$ Ostrowski, 'O lasce marszałka sejmu z lat 1830-1831', p. 184.

${ }^{63}$ Żygulski, Dzieje polskiego rzemiosta artystycznego (Warsaw, 1987), p. 32.

${ }^{64}$ Pamiętniki pana de Beaujeu 1679-1692, p. 343. The Polish historian Lileyko uses this source in writing about the batons of sejm marshals, although it definitely refers to the grand marshal and his insignia.

${ }^{65}$ This portrait is published in Marszałkowie sejmów i Rzeczypospolitej, ed. W. Sieradzki (Warsaw, 1993), p. 51. Its brass engraving is kept in the National Museum of Poland, Warsaw, inventory no. Gr.Pol. 13271.

${ }^{66}$ Pamiętniki pana de Beaujeu, p. 343.

${ }^{67}$ Ibid. 

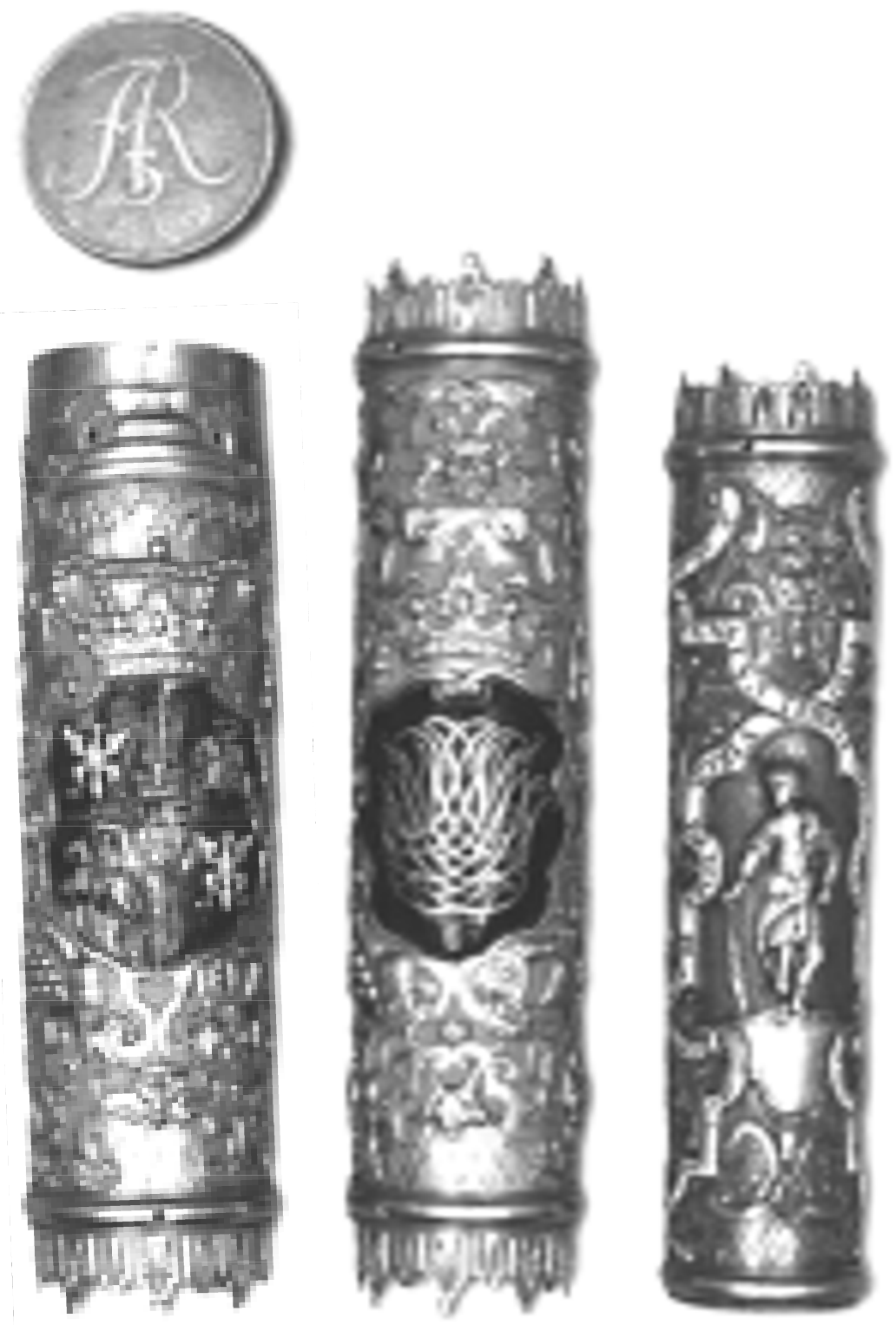

Fig. 4. Bindings of the Baton of GDL Court Marshal Juozapas

Scipionas (1739-1744).

J. Gierowski, Rzeczpospolita $w$ dobie złotej wolności. Wielka historia Polski, vol. 5 (Cracow, 2001). 
Lithuanian mounted knight in the second and third fields and the Saxon emblem in the centre. The middle part of the baton was ornamented with the crown and beneath it an escutcheon. The bottom showed a human figure leaning on the staff. A ribbon on both sides of the figure contained an inscription (cf. Fig. 4).

Iconographic material presents much information on the appearance of the batons of the GDL marshals. Thus, the baton is clearly seen in marshal K. Veselovskis' portrait, painted in 1636. It is a long ebony baton reaching nearly the shoulders of the marshal. It is slightly thicker towards the top, and its ends and the middle are bound round with metal. Sigismund III Vasa's monogram ST (Sigismundus Tertius) is surmounted by the royal crown (see Fig. 1). Although the portrait was painted already during the reign of Władysław Vasa and at the time when Veselovskis was grand marshal, it is believed that he was portrayed as Sigismund III Vasa's court marshal the duties of which he carried out between 1623 and $1635 .^{68}$

Particularly beautiful is the baton in K. Zaviša's portrait. The ends and the middle part of the baton are bound with precious metal, decorated with floral ornaments, and set round with turquoise and rubies.

In other portraits the marshal batons are much more abstract. ${ }^{69}$ Sometimes they are not held by the officers themselves, but are in some way integrated into the coat of arms. For example, in a halflength portrait of A.L. Radvila the baton is kept by the Radvila eagle in its right foot at the bottom of the portrait. ${ }^{70}$

Baton Presentation Ceremony The marshal was appointed by the sovereign. No information about the appointment ceremonial could be found prior to the middle of the sixteenth century. It can only be assumed that the appointed official had to take an oath to perform his duties suitably. According to contemporary traditions, the oath had to be sworn in a church or some other place in the presence of a clergyman. The words of the oath had to be uttered with two fingers touching the cross or the Bible. ${ }^{71}$ The first recorded

68 J.T. Petrus, T.A. Karpowicz, Portrety osobistosci dawnej Rzeczpospolity $w$ zbiorach Mińskich, Katalog wystawy (Cracow, 1991), p. 15.

${ }^{69} \mathrm{Cf}$ the sixteenth - early seventeenth century portrait of M. Šimkevičius, grand marshal of the Grand Duchy between 1550 and 1563, the middle of the seventeenth century portrait of Aleksandras Liudvikas Radvila, grand marshal in 1637-1654, and the portrait of Ignotas Zaviša, court marshal of the GDL, 1736-1738.

${ }^{70}$ The portrait had been kept in the Nesvyžius gallery; it was published in B. Taurogiński, $Z$ dziejów Nieświeża (Warsaw, 1937), p. 49.

${ }^{71}$ V. Raudeliūnas, 'Priesaika kaip įrodymas senojoje Lietuvos teisèje (XIIIXVI a. pr.)'. Socialistinè teise, no. 1 (1974), p. 56. 
text of the GDL grand marshal's oath goes back to the first half of the sixteenth century. ${ }^{72}$ The marshal swore allegiance by God to the ruler, his heirs and the Grand Duchy of Lithuania, and he undertook to carry out his duties honestly and to adhere to the provisions of the Lithuanian Statute. ${ }^{73}$ Similarly, oaths of allegiance were sworn by Polish marshals to the kings of Poland, and promises were made to adhere to the provisions of Polish statutes. ${ }^{74}$ A question arises concerning the unification of the texts of oaths after the Union of Lublin. The oath of the Polish marshal, recorded in 1600, is known to coincide closely with a sixteenth-century oath. ${ }^{75}$ In the middle of the eighteenth century J. Ostrowski-Daneykowicz published a text of the marshal oath of the two nations. ${ }^{76}$ However, it fully coincided with the seventeenth century oath of the Polish marshal. This oath, nevertheless, related only to the Polish king and Polish statutes, and no mention was made of Lithuanian grand dukes and statutes. The disregard of the grand duke could be understandable, because the title of the grand duke was also omitted in the oath of the hetmans of the two nations written in $1717 .{ }^{77}$ The officials swore their allegiance to the king of Poland and to the Commonwealth of the Two Nations. However, a Lithuanian official could not pledge allegiance by the Polish statutes. Therefore, it could be deduced that Ostrowski-Daneykowicz did not publish an oath of the marshals of the two nations, instead he made a copy of an earlier version of Polish marshals. Meanwhile after the Union of Lublin the officials had to swear allegiance to the sovereign, his successors and the Commonwealth of the Two Nations.

The sources of the early seventeenth century witness an already fully-fledged ceremonial of the nomination of the marshal, eloquent speeches and the handing over of the baton. ${ }^{78}$ The solemn cer-

72 Lietuvos Metrika. Knyga nr. 530 (1566-1572). Viešuju reikalu knyga 8 (Vilnius, 1999), pp. 22-23.

${ }^{73}$ Ibid. As allegiance was sworn to the King of Poland and the Grand Duke of Lithuania Sigismund Augustus, it can admitted that the text of the oath was recorded after his coronation in 1529 or on his actual ascension to the throne following his father Sigismund the Old's death in 1548.

${ }^{74}$ Ibid., pp. 29-30.

75 J. Januszowski, Księgi pierwsze królewskie (Cracow, 1600), p. 293.

76 J. Ostrowski-Daneykowicz, Swada polska i lacinska, cz. 3. Swada kancelaryina, p. 46.

$77 V L$, vol. 6 (Petersburg 1860), pp. 126, 128.

${ }^{78}$ One of the earliest (1603) descriptions of the nominations of Polish marshals is found in [P. Piasecki] Kronika Pawła Piaseckiego, biskupa Przemyślskiego (Cracow, 1870), p. 173. The nominations of the GDL marshals, known since the 
emony took place in the sejm. After the nomination the newly appointed marshal received a baton from the former marshal if the latter was given a higher post. If the new marshal was appointed following his predecessor's death, the baton was handed in by the chancellor or vice-chancellor. ${ }^{79}$ As a rule, a Lithuanian official presented a Lithuanian marshal with a baton. However, in the absence of a particular GDL official at the sejm a corresponding Polish official could perform that duty. A solemn speech, exalting the virtues of the candidate and the symbol of the authority, always preceded the presentation of the insignia. ${ }^{80} \mathrm{Cf}$. the words of the Polish court marshal Franciszek Bieliński on the occasion of presenting the baton of the GDL marshal to J. Scipionas:

Take that baton which is the symbol of supreme authority; take the baton that defends the weak and punishes the wicked; the baton that goes before the King and is followed by the laws; and lastly, take the baton with which the marshal defends the King and guards the laws. ${ }^{81}$

In this way the marshal was reminded of his duties. On receiving the baton the new marshal made an oath, the text of which was read by the GDL chancellor or vice-chancellor. Then the marshal delivered a speech in which he eulogised the sovereign and his merits to the state and the people and expressed his gratitude for the conferment of the office. ${ }^{82}$ Scipionas' words were a sort of response to Bieliński's speech: 'My Lord, I take this baton as your attendant, as the controller of voices and suppresser of disturbances'. ${ }^{83}$ These phrases specified precisely the functions of the marshal's baton. The marshal accompanied the sovereign with the baton in his hand. Knocking on the floor, he restored order or introduced the speaker. Sometimes he used the baton to maintain discipline. After his acceptance speech

middle of the seventeenth century, did not differ in any way from those of the Polish marshals.

${ }^{79}$ Schultz, Commentarius, p. 5.

${ }^{80}$ Kronika Pawła Piaseckiego, p. 173.

${ }^{81}$ Mowa J. W. Imci Pana Bielińskiego marszałka nadwornego koronnego oddaiąc J.W. Panu Scypionowi staroście Lidzkiemu laskę nadworną W. X. Lit., Swada Polska, cz. 1, p. 92.

${ }^{82}$ Mowa J. W. Jm Pana Dołskiego podczaszego WXL dziękuiąc za laskę nadworną litewską, Swada polska, cz. 1, pp. 41-42; Dziękowanie za laskę nadworną WXLit. Przez J.W. Imci Pana Tyszkiewicza podskarbiego nadwornego W. X. Lit., Swada polska, cz. 1, pp. 234-235.

${ }^{83}$ Mowa J. W. Imci Pana Jozefa Scypiona starosty Lidzkiego dziekuiąc za ląske nadworną W.X. Lit., 1740, Swada polska, cz. 1, pp. 92-94. 
the new marshal kissed the ruler's hand and immediately began discharging his duties. ${ }^{84}$

When the court marshal was upgraded to grand marshal, no oath swearing ceremony took place, because the official did not have to make one more oath. The oath was the same for the court and grand marshal. However, with the arrival of a new sovereign the officials had to swear allegiance anew despite their former oath to his predecessor. ${ }^{85}$

According to contemporaries, after having received the baton the marshal could not appear without it in the court even if he did not accompany the sovereign. The baton was carried by a gentleman following the marshal. Entering the royal chambers the marshal took it in his hand. ${ }^{86}$ With the baton in their hands the marshals proclaimed the election of a new ruler, participated at his coronation, conducted the ceremonies at the sejm and diplomatic receptions, guided the ceremonials of the name days of the royal members, their parties, funerals, etc. ${ }^{87}$

Following the Union of Lublin in 1569, the competence of the Polish and Lithuanian marshals was established at the same sejm of Lublin. The GDL marshals performed their official duties when the sovereign was on a visit in Lithuania, and the Polish marshals acted respectively in Poland. However, on 19 July 1569 the GDL marshals were given the right to take part at the reception of foreign envoys together with Polish marshals in Poland. Since 15 March 1572 they could attend any ceremonies together with Polish marshals. ${ }^{88}$ Certainly, the ceremonials were led by Polish marshals. When the sovereign was in Poland and the Polish grand marshal was absent, he was replaced by the grand marshal of the GDL. The competence of the Lithuanian court marshal was rather limited. He could conduct ceremonies only in the absence of both Polish marshals and the Lithuanian grand marshal.

\section{The GDL Marshals in the Ceremonials of Royal Election and} Coronation Prior to the Union of Lublin the GDL marshals

${ }^{84}$ Lengnich, Prawo pospolite, p. 272.

${ }^{85}$ S. Ochmann, 'Koronacja Jana Kazimierza w roku 1649', Odrodzenie $i$ Reformacja w Polsce, vol. 28 (1983), p. 174.

86 Pamiętniki pana de Beaujeu, p. 343.

${ }^{87}$ Schultz, Commentarius, pp. 11-31.

${ }^{88}$ A. Rachuba, 'Udział urzędników Wielkiego Księstwa Litewskiego w uroczystościach państwowych Rzechypospolitej w latach 1574-1764', Theatrum ceremoniale na dworze królów i ksiażat polskich (Cracow, 1999), p. 151. 
participated in the ceremonial of the elevation to dukedom. In the cathedral when the bishop of Vilnius put a crown on the head of a new grand duke, the land marshal solemnly presented him with an unsheathed sword and begged him to rule according to Lithuanian laws and customs. ${ }^{89}$ Failing to preserve this tradition at the sejm of Lublin, the GDL marshals acceded unwillingly to the ceremonial of the election and coronation of the common ruler of Poland-Lithuania.

The functions of marshals in the electoral sejm were institutionalised finally during the election following Sigismund August's death in 1572. In the first place, the marshals had to maintain order in the electoral field. They had to indicate each palatinate a separate place for the sessions and to maintain law and order. ${ }^{90}$

Another important function of the marshals was to inform about the election of a new ruler. In the electoral sejm of 1572 there was a conflict between the archbishop of Gniezno and the marshals because the archbishop announced the election of Henri Valois, thus allegedly violating the marshals' rights. ${ }^{91}$ Nevertheless, an agreement was reached and luckily no second election was necessary. Subsequently it was established that after the election the archbishop could only nominate the ruler elect and had to ask the marshals to inform the whole sejm about it. One source stated that each marshal participating in the ceremony delivered a speech. ${ }^{92}$ According to other sources, only the grand marshal of Poland spoke on behalf of all other present marshals. ${ }^{93}$ Most probably both options were possible. Henri Valois' election as king of Poland and grand duke of Lithuania was reported to have been announced by three marshals the grand marshal of Poland J. Firliej, the court marshal of Poland A. Opaliński and finally the grand marshal of Lithuania J. Chodkevičius. ${ }^{94}$ In his memoirs Władysław Vasa's physician wrote that at the archbishop's request the election of the new ruler was announced by the grand marshal of Poland (with one more marshal participating): 'As befits my office, on behalf of my colleague and

\footnotetext{
${ }^{89}$ Kronika Marcina Bielskiego (Warsaw, 1764), p. 431.

${ }^{90}$ Schultz, Commentarius, pp. 25-28.

91 O elekcyi Henryka Walezyusza na króla polskiego, p. 242.

92 Vorbek-Lettow, Skarbnica pamięci, p. 73.

93 Pamiętniki do panowania, vol. 1, p. 201.

${ }^{94}$ O elekcyi Henryka Walezyusza na króla polskiego, p. 255.
} 
me, I declare Władysław Vasa, King of Sweden, Prince of Poland, elected as King of Poland by the ballots of all the estates of this Crown'. 95

The place, where the election of the king was announced, could vary, too. Thus the election of Władysław Vasa was declared by the marshals standing on the electoral field, at the place of the Senate's session. ${ }^{96}$ Following the election of Stanisław August the marshals went to the four gates of the rampart surrounding the electoral field, so that people on the other side of the rampart could hear the news. ${ }^{97}$ Meanwhile, W. Skrzetuski mentioned only three gates - the Western of Greater Poland, the Southern of Lesser Poland and the Eastern Gate of the GDL. ${ }^{98}$ This is also attested by the seventeenth and eighteenth century iconography; in the plans of the electoral field only three gates of the rampart are shown. ${ }^{99}$

After the nomination the king-elect had to swear to the Pacta Conventa. In the seventeenth and eighteenth centuries the oath ceremony took place in the Church of St John in Warsaw. After the oath the marshals had to read the act of the royal election on the steps of the Church to those present and to announce that the act was handed in to the new sovereign. ${ }^{100}$ After that the marshals started accompanying him with their batons. However, while leaving the Church, they were still lowered because despite his oath the king-elect did not yet possess full rights. Besides, his predecessor was not yet buried. The marshals raised their batons only during the ceremony of the coronation. ${ }^{101}$

95 Vorbek-Lettow, Skarbnica pamięci, p. 73. Meanwhile W. Kaczorowski noted that all four marshals participated in this sejm. He also indicated different phrases in which the grand marshal of Poland Opaliński announced the election of the king: 'Noble Sirs, I have the honour to inform you that we already have the King of Poland and the Grand Duke of Lithuania, Prince Władysław, the eldest son of the deceased His Majesty King ...' Kaczorowski, Sejm konvokacyiny i elekcyiny $w$ okrese bezkrólewia 1632 r. (Opole, 1986), p. 308.

96 Vorbek-Lettow, Skarbnica pamięci, p. 73.

97 J. Kitowicz, Pamiętniki czyli historia polska (Warsaw, 1971), p. 124; Elekcje królów polskich, ed. M. Tarczyński (Warsaw, 1997), p. 216.

${ }^{98}$ Skrzetuski, Prawo polityczne, p. 95.

99 These plans are published in Elekcje królów polskich.

${ }^{100}$ Pamiętniki do panowania, vol. 1, p. 203.

${ }^{101}$ In his diary the palatine of Vitebsk, J.A. Chrapowicki, indicated incorrectly that in 1669 after the election of Michał Korybut Wiśniowiecki the marshals immediately raised their batons and announced the election of the sovereign. See Dyariusz wojewody witebskiego Jana Antona Chrapowickiego, p. 131. 
The activity of the marshals began in the coronation by coordinating the procedure of the ceremonial and by appointing persons to carry the royal insignia. Then they dressed the king in coronation robes. That was usually performed by the grand marshal of Poland; and sometimes the ruler was dressed by a bishop. ${ }^{102}$ On the way to the Cathedral the marshals' batons were still lowered. They accompanied the ruler with their batons raised on his way to the throne after his coronation and investment with the sceptre. ${ }^{103}$ When the ceremony was over with everybody present shouting Vivat Rex, the marshals declared the coronation of the new king and since that moment they accompanied him everywhere with their batons raised. ${ }^{104}$ They bore the batons upraised in both hands like a cross in the procession.

The GDL marshals participated in the election and coronation of Henri Valois (1573), ${ }^{105}$ Władysław Vasa, ${ }^{106}$ Jan Kazimierz Vasa, ${ }^{107}$ Michał Korybut Wiœniowiecki, ${ }^{108}$ Jan Sobieski, ${ }^{109}$ August III, ${ }^{110}$ and Stanisław August Poniatowski. ${ }^{111}$

Marshals in Court Ceremonial During the coronation a raised baton was borne by the marshal before ruler everywhere where he appeared in public - going to the church, to the sejm, in the processions and even during the court feasts. ${ }^{112}$ The grand and court marshals carried the batons only before the king. Therefore the queen and other members of the royal family had to walk several steps behind, so that there would be no doubts before whom the baton was being carried. ${ }^{113}$ In the seventeenth and eighteenth centuries

102 Ochmann, Koronacja Jana Kazimierza, p. 153.

${ }^{103}$ Radziwiłł, Memoriale, vol. 1, p. 169.

104 Dwie koronacye Sasów, Augusta II i Augusta III królów polskich, ed. W. Syrokomla (Vilnius, 1854), p. 44.

${ }^{105}$ Rachuba, 'Udział uzrędników', p. 157.

${ }^{106}$ Pamiętniki do panowania, vol. 1, p. 180; republished in Elekcje królów polskich, pp. 137-152; M. Radoszewski, Diariusz koronacyjej naijaśniejszego Wtadystawa Zygmunta IV, p. 33.

${ }^{107}$ Rachuba, 'Udział uzrędników', p. 152.

${ }^{108}$ Ibid., p. 158.

109 Elekcja Jana III Sobieskiego 20 kwietnia - 9 czerwca 1674, Elekcje królów polskich, p. 192.

110 Dwie koronacje Sasów, pp. 33-41.

111 Kitowicz, Pamiętniki, p. 142; republished in Elekcje królów polskich, pp. 216; Rachuba, Udział uzrędników, pp. 161-162.

112 F. Fuchs, 'Ustrój dworu królewskiego za Stefana Batorego', Studya historyczne wydane ku czci prof. W. Zakrzewskiego (Cracow, 1908), p. 65.

113 J. Lileyko, Życie codzienne w Warszawie za Wazów (Warsaw, 1984), p. 162. 
other members of the royal family and even some noblemen (e.g. the archbishop of Gniezno) had marshals in their courts. ${ }^{114}$ And the batons were carried before them, too. However, if a particular ceremony was attended by the sovereign, the batons of other marshals were either not used at all or carried lowered. ${ }^{115}$

If in a solemn entry the ruler rode on horseback, he was preceded by mounted marshals with batons in their hands. Thus a seventeenth-century frieze in the royal castle of Warsaw shows the entry of Sigismund Vasa and Duchess Constance into Cracow on 4 December 1605. The ruler is depicted on a charger with Polish and Lithuanian marshals with their batons riding on horseback before him.

When in the late seventeenth and especially in the eighteenth century both the ruler and his marshals usually rode in carriages, the carriages of the marshals always went before that of the ruler. If all marshals participated in the cortege, the first carriage was that of the court marshal of the GDL, followed by the carriages of the court marshal of Poland, of the grand marshal of the GDL, of the grand marshal of Poland and finally of the ruler. ${ }^{116}$

In his diary the chancellor of the GDL Stanislovas Albrechtas Radvila stated that bearing the batons before the ruler was a purely Polish ceremonial and caused great surprise and enjoyment for European envoys. It was a mark of respect for the sovereign, and therefore that ceremony was particularly strictly observed. However, despite the fact that there were four marshals in the Commonwealth, there were cases when on a certain occasion none of them happened to be present at the court. Therefore, provision was made for such a situation - the baton could be carried by some other official of the state - the chancellor, vice-chancellor, and in their absence by the treasurer. For example, on 26 April 1640, in the absence of the marshals, the Polish vice-chancellor, Jerzy Ossoliński, carried a marshal's baton before Władysław Vasa on his way to the sejm hall. ${ }^{117}$

114 'Relacya o stanie politycznym i wojskowym Polski przez Sebestyana Cefali sekretarza Jerzego Liubomirskiego marszalka i hetmana polnego koronnego z roku 1665', Relacye nuncyuszów apostolskich, vol. 2, p. 309; Pamiętniki Jana Duklana Ochockiego, ed. J.I. Kraszewski (Vilnius, 1857), vol. 1, p. 98.

115 'Ceremonial przyimowania Xiążęcia Prymasa do przysięgi i na pierwszą audyencyą do Króla', Cracow, Biblioteka PAN i PAU, 334, fo. 283v.

116 Dyariusz inwestitury Nayjasnieyszego Królewicza Jmci na Xięstwo Kurlandzkie 157901 08, Cracow, Biblioteka PAN i PAU, 334, fos. 381-382.

${ }^{117}$ K. Przyboś, 'Finanse królewskie a ceremonial na dworze Władysława IV', Theatrum ceremoniale, p. 273. 
In April 1787 the baton was carried by the GDL vice-chancellor, J. Chreptavičius, before Stanisław August Poniatowski who was going from the cathedral to the castle; several days later the same function was performed by the field hetman of the GDL, L.S. Tiškevičius. ${ }^{118}$ That was an exceptional case, which created a stir and even discontent since the hetman was not entitled officially to carry out such duties. However even this regularisation could not foresee all probable cases, and there were situations when there was nobody to carry the baton. In 1680 when Jan Sobieski attended the festival of Corpus Christi in the Church of St John in Warsaw the marshal's baton was not carried at all. At that time the grand marshal of Poland was at the court, however due to some disagreements with the king he refused to carry the baton, and there was nobody else to replace him. ${ }^{119}$ In the absolutist monarchy such a situation would hardly be conceivable. However, in PolandLithuania, in the atmosphere of gentry democracy, such a phenomenon was customary.

During royal receptions the marshal stood with his baton at the sovereign's table and supervised the serving of meals. ${ }^{120}$ After the sovereign drank his first glass, the marshal could take his place at the table. ${ }^{121}$ Sometimes the baton was used according to its original purpose - to maintain order or to make way for the ruler in the crowd. ${ }^{122}$ During the wedding feast of the royal steward Adam Kazanowski the baton propped up the canopy to prevent it from falling on the ruler. ${ }^{123}$

Marshals in Envoy Reception Ceremonies The envoy had to be attended to as soon as he crossed the state border. An escort of one or several persons had to ensure his welfare and safety. At first the escort was appointed by the grand duke of Lithuania himself. In the sixteenth century it became the duty of the marshals. After the Union of Lublin only envoys from the East - Russians, Turks, and Tartars - were met at the border. Possibly this tradition was

118 Wyzyty Królewskie. Wspomnienia o obyczaju dworskim z czasów Stanistawa Augusta Poniatowskiego, ed. S. Truchim (Poznań, 1926), pp. 70, 78.

119 Pamiętniki pana de Beaujeu, p. 343.

${ }^{120}$ Lileyko, Życie codzienne, p. 165.

121 'Relacya ceremoniy oddawania birety Kardynalowi Salernie 2 kwietnia 1720', Cracow, Biblioteka PAN i PAU, 335, fo. 52v.

122 Lileyko, Życie codzienne, p. 162.

${ }^{123}$ Radziwiłł, Ceremoniale, vol. 2, p. 35. 
related with the fact that the eastern policy of the united state remained the competence of the GDL.

After the envoy's stay in the immediate vicinity of the capital it was the marshal's duty to organise his solemn entry into the city. The scale of the solemnity depended on the rank of the envoy and on the character of the relations of Poland-Lithuania with the state of the envoy. The most solemn were the receptions of papal nuncios and foreign ambassadors. ${ }^{124}$ The marshal fixed the date of a solemn entry; all senators and courtiers had to be informed about it so that they could participate in the procession to make an escort to the envoy 'in honour of His Royal Majesty and the Commonwealth'. ${ }^{125}$ In the late sixteenth and early seventeenth centuries the papal nuncios were met by the ruler himself and his officials and courtiers at the city gates. The marshals also took part in this ceremony. For example, the Polish grand marshal, Mikołaj Zebrzydowski, with his baton in hand rode before the king in meeting the papal envoy Cardinal Gaetano on 22 September $1596 .{ }^{126}$ The grand marshal was followed by the standards of the marshal and royal horsemen. King Sigismund Vasa and his retinue followed them, and the court marshal of the GDL Kristupas Manvydas Dorohostaiskis rode alongside the king. ${ }^{127}$

To meet other envoys the marshal delegated two senators, one Polish, the other Lithuanian, to accompany the guest in a royal carriage to the apartments reserved for him. ${ }^{128}$ Meeting Turkish or Tartar envoys the marshal asked the hetman to appoint several officers to escort them. ${ }^{129}$ The following day the envoy could pay a visit to the marshal in his palace, to present his credentials and ask

${ }^{124}$ In greater detail about the ranks of envoys, see R. Przeżdiecki, 'Ceremonial dyplomatyczny w dawnej Polsce’, Sprawy obce, z. 1 (1929), pp. 17-21; B. Filipowicz, Ogólne zasady protokolu dyplomatycznego (Warsaw, 1967), pp. 19-21; Dyplomaci $w$ dawnych czasach. Relacje staropolskie z XVI-XVIII stulecia, ed. A. Przyboś and R. Źelewski (Cracow, 1959), pp. 49-50.

125 'Informacyja przyiencia posła od Porty Ottomańskiey, spisana w Warszawie 1 marca 1755', Cracow, Biblioteka PAN i PAU, 334, fo. 236.

${ }^{126}$ J.P. Mucante, 'Diariusz legacji kardynala Gaetano', Cudzoziemcy o Polsce, vol. 1, p. 191.

${ }^{127}$ Ibid., pp. 191-192.

128 'Projekt do ceremonialu na investiturę Nayjaśnieszego Królewicza Imci Karola na Xięstwo Kurlandskie y Semigalskie do której iest determinowany dzień drugi lutego 1759', Cracow, Biblioteka PAN i PAU, 334, fo. 356v.

129 'Ceremonial według dawnego zwyczaju regulowany audiencyi posła tatarskiego w Grodnie na seimie ordynaryinym 1752', Cracow, Biblioteka PAN i PAU, 334, fo. 215 . 
for an audience with the sovereign. The envoy's reception in the marshal's palace was held in the audience hall in the presence of senators. The marshal and the envoy sat on sofas, the former on the left and the latter on the right sofa. The selection of a particular sofa was conditioned by the established ceremonial - the seat of honour was on the right side. Between the sofas there was a table on which the marshal's insignia lay - a baton decorated with precious stones; it was a sign indicating that the envoy was in audience with a state official. ${ }^{130}$

This practice came to an end in the eighteenth century, in August III's times, when Saxon officials began taking over the functions of state officials of Poland-Lithuania. At that time some envoys of Western European states (Spain, or France) paid their first visit not to the state marshals but to the Saxon prime minister Brühl. ${ }^{131}$ French ambassadors also endeavoured to get certain privileges by requiring that the first visit would be made by the state marshal to the ambassador rather than vice versa as had been until that time. However, the grand marshal of the GDL, P.K. Sanguška, thwarted these attempts by categorically refusing to be the first to visit the French ambassador who arrived in Grodno in October 1744. ${ }^{132}$ The outcome of the conflict was the failure of the envoy to be received by the ruler. ${ }^{133}$ A similar situation arose with Russian ambassadors in the latter half of the eighteenth century. In 1769 the new Russian representative to Warsaw, M. Volkonskii, evading the first visit to the marshal, proposed to send his credentials through his secretary and insisted that the marshal made his visit to him first, thus doing honour to Russia. ${ }^{134}$ Perceiving that such a step would humiliate his state, the marshal emphatically rejected the offer. Finally a compromise was reached. The ambassador presented his credentials through his representative, and the marshal informed the ambassador about the reception at the ruler through his representative, too. The envoys of other states continued to present their credentials to the marshals by themselves.

${ }^{130}$ Krutta, Dziennik, p. 26.

${ }^{131}$ Przeżdiecki, 'Ceremonial dyplomatyczny', p. 23.

132 M. Skibiński, Europa a Polska $w$ dobie wojny o sukcesye austryacka w latach 1740-1745, vol. 1 (Cracow, 1913), p. 690.

${ }^{133}$ Ibid. p. 691.

${ }^{134}$ Opisanie audiencyi xiążąt Ich Mci Repnina z pożegnaniem, Wolkonskiego z powitaniem, Akta ceremonialów publichnych, AGAD, AZ, ms. 3061, fos. 119-124. 


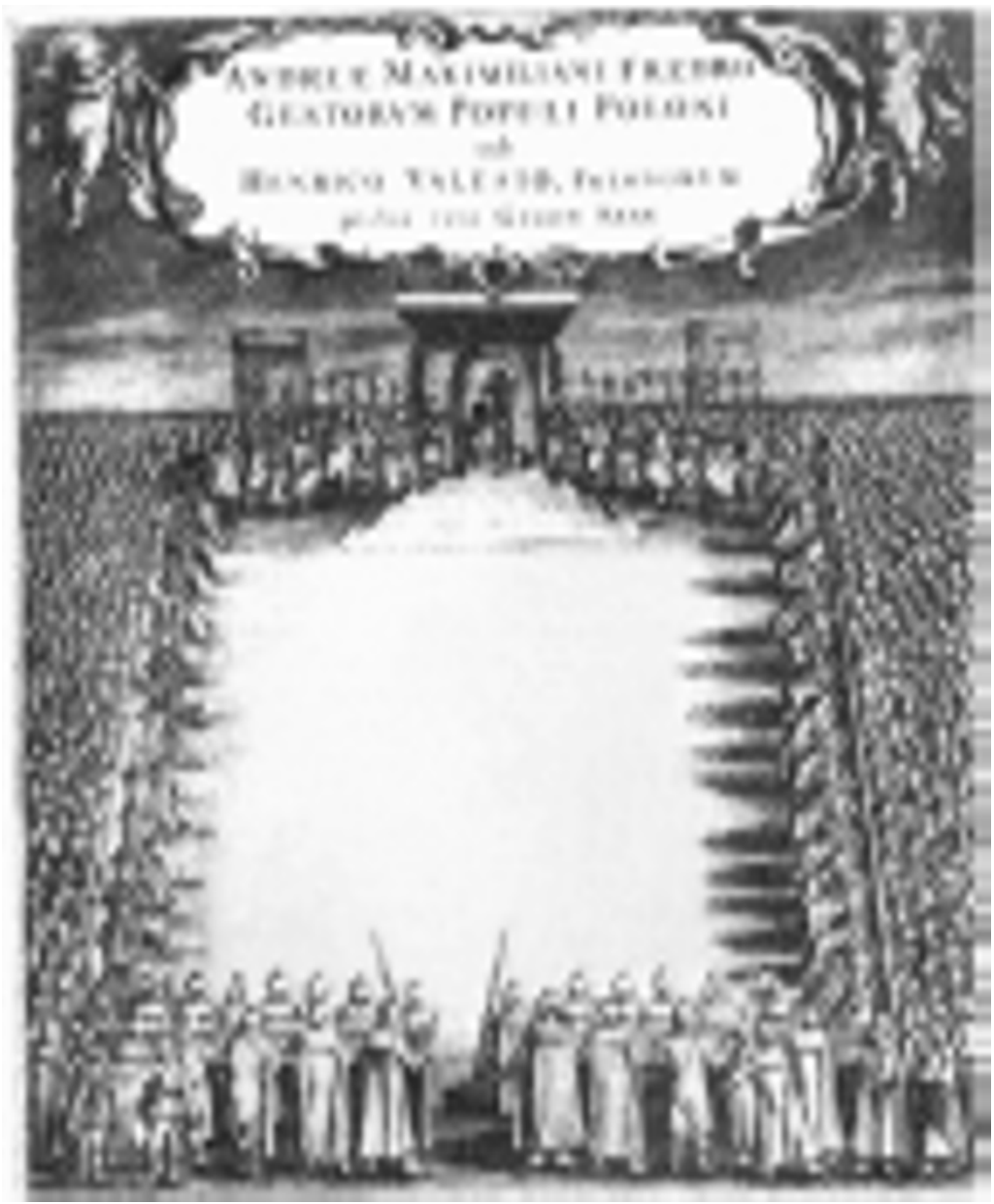

Fig. 5. Marshals in the Sejm Ceremony, 1652.

J.S. Bystron, Dzieje obyczajów w dawnej Polsce, vol. 2 (Warsaw, 1976).

A.M. Fredro, Gestorum populi Poloni sub Henrico Valesio, the Czartoryski Collection, Cracow. 
The timing of the audience was fixed with the ruler. Then the envoy was informed and details of his arrival and reception were discussed. The cavalcade accompanying the envoy to the ruler was even more solemn than the one of his entry into the capital. Again two senators and carriages were sent. ${ }^{135}$ Meanwhile the marshals with batons in their hands accompanied the sovereign into the Senate Hall. On his arrival the envoy was met by the same marshals. This function of the marshals was familiar in the GDL already in the late fifteenth century. However then it was not yet settled where the marshals had to meet the arriving envoys. Depending on the envoy's rank, the marshals could meet him on the porch of the royal palace or even at the place of his stay. ${ }^{136}$ In the seventeenth and eighteenth centuries the ceremonial became established - the court marshals met the envoys in the antechamber of the hall and the grand marshals at the door to the hall or in the hall itself. When particular homage had to be paid to the envoys, the waiting area of the marshals was the stairway leading to the castle. ${ }^{137}$ They met the envoy with their batons which were lowered. ${ }^{138}$ The envoy walked between the marshals. If only one official participated in the ceremony, the guest was always given the right side. In the hall his place was in front of the ruler's throne between the chairs of the grand marshals (Fig. 5). ${ }^{139}$ Meanwhile the marshals with their batons again raised occupied their places at the ruler (Fig. 6). ${ }^{140}$

During the audience knocking with the batons several times to the floor, the marshals gave the right to speak to both the envoys and the chancellor addressing on behalf of the sovereign. They also indicated the participants when to sit down and when to get up. Descriptions of the audiences clearly illustrate how the marshals conducted the ceremonial. For example, on 25 August 1777 two

135 'Ceremonial de l'entrée de M. Marquis de Monti ambassadeur de France á Varsovie, 1732', Cracow, Biblioteka PAN i PAU, 335, fos. 27r-v; 'Ceremonial wedlug dawnego zwyczaju regulowany Audiencyi posla tatarskiego w Grodnie na seymie ordynaryinym 1752 ', ibid., fos. 214-215.

136 Sbornik, vol. 35, p. 142,

${ }^{137}$ Lileyko, Życie codzienne, p. 57,

138 'Opisanie wjazdu, audiencyi y wykonania homagii circa investituram xięcia Kurlandzkiego Ferdynanda, 173102 25`, Cracow, Biblioteka PAN i PAU, 334, fo. 333.

139 'Ceremonial według dawnego zwyczaju regulowany audiencyi posła tatarskiego w Grodnie na seimie ordynaryinym 1752', ibid., fo. 215.

140 'Dyariusz inwestitury Nayjasnieyszego Królewicza Jmci na Xięstwo Kurlandzkie 8 stycznia 1759’, ibid., fo. 384. 


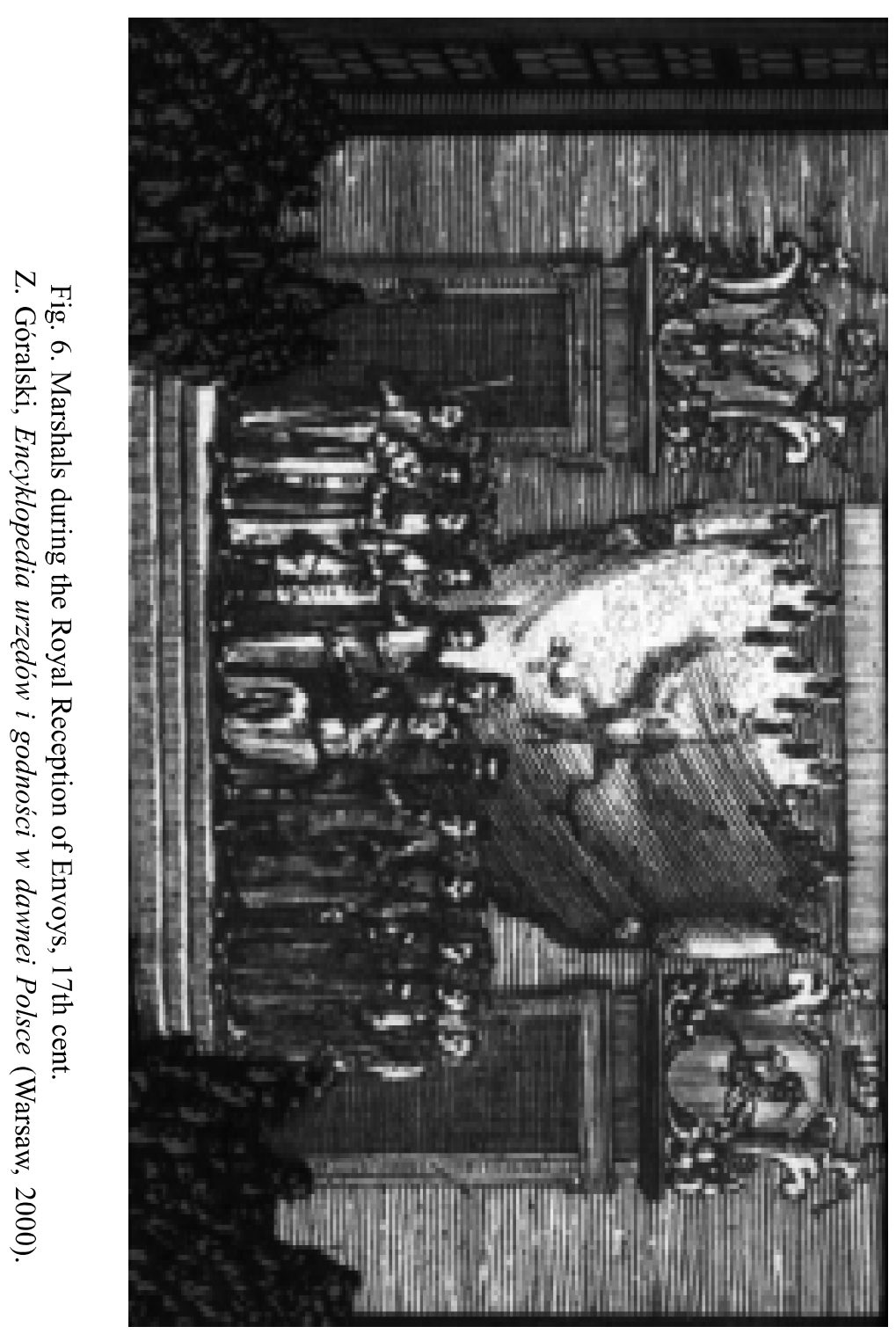


marshals (of Lithuania and Poland) after a brief talk with the ruler, struck the floor with their batons three times, and the Polish marshal invited the envoy to come up to the throne. After the chancellor took his letters of credence, the marshal asked the envoy to go back to his place and told the officials to provide cushions for him to sit. Then the marshal returned back to the throne and after a conference with the ruler again struck three times with his baton, thus giving the floor to the envoy. His speech being over, the marshal again struck three times with his baton and presented the chancellor. Again striking three times with his baton, the marshal let the interpreter translate the chancellor's speech into Turkish. ${ }^{141}$ The baton was knocked each time when a new official was given the floor. The audience was often followed by a solemn dinner, and the marshal was responsible for the seating plan. ${ }^{142}$

The envoy left the palace in the order resembling his arrival. The grand marshals, with their batons lowered, accompanied the envoy to the door of the hall, the court marshals led him to the middle of the antechamber, and further he was escorted by other senators. ${ }^{143}$ Meanwhile the marshals returned to the Senate Hall and accompanied the ruler with their raised batons.

After the Union of Lublin the GDL marshals were responsible for the reception of envoys in the territory of Lithuania and for the reception of Russian envoys both in Poland and Lithuania. ${ }^{144} \mathrm{How}-$ ever, very often this distribution of competence was not observed. Poland's officials endeavoured to lead in the ceremonial both in the GDL and in the reception of Russian envoys in Warsaw. For example, in 1728, in Grodno, the ceremony of the reception of the papal envoy and the Austrian ambassador was conducted by the grand marshal of Poland, Józef Mniszech, although the grand marshal of the GDL, Aleksandras Povilas Sapiega, took part in the festivities as an equal. ${ }^{145}$ Consequently, some of the contemporaries stated that

${ }^{141}$ Krutta, Dziennik, p. 33.

${ }^{142}$ More on this ceremonial. see Z. Tażbierski, 'Zasady pierwszeństwa w ceremoniale biesiadnym podczas pryjmowania obcych posłów w Polsce', Przeglad Historyczny, (1981), z. 3, pp. 23-49.

143 'Ceremonial audjencyi publicznej Jego Excellencyi księdza Garampi', Zbiór pamiętników do dziejów polskich, ed. W.S. hr. de Broel-Plater (Warsaw, 1858), p. 218.

${ }^{144}$ Przeżdiecki, 'Ceremonial dyplomatyczny', 26.

${ }^{145}$ H. Perzanowska, 'Urząd marszałkowski w okresie rządów Józefa Mniszcha', Acta universitatis Wratislaviensis, no. 54, Historia XII (Wrocław, 1966), p. 84. 
the grand marshal of Poland predominated on the territory of the GDL as well. ${ }^{146}$ When a new Russian ambassador, M. Volkonskii, came to Warsaw in 1769, he presented his credentials, in contrast to his predecessor, to the grand marshal of Poland, S. Liubomirskii, rather than to a Lithuanian high official. ${ }^{147}$ In 1793 the Russian diplomat, Jakob Sievers, applied to the grand marshal of Poland and presented his credential letters. ${ }^{148}$ That situation often led to discord, the distribution of competence was reviewed, but things did not change. ${ }^{149}$

Marshals in Sejm Ceremonial Like during the audiences, the marshals conducted the ceremonials of the sejm and of the Senate. The procedure of the House of Representatives was supervised by the sejm marshal, elected every time from among the deputies. The marshals of the GDL performed this duty when the sejm was in session in Grodno, i.e. every third time. Having assembled all delegates went to the Hall of the Senate to greet the king. The marshal met them in the antechamber and accompanied to the Hall. Knocking his baton the marshal gave the floor to the marshal of the sejm to greet the ruler on behalf of the whole sejm. After the greeting the marshal again knocked to the floor and let the chancellor deliver a speech on behalf of the king. The speeches over, he again struck three times with his baton and called on the participants to kiss the ruler's hand. ${ }^{150}$ Later, knocking his baton he announced that the delegates could leave the Hall.

During the sessions it was the marshal's duty to meet the delegations coming to the Senate for joint tasks. The marshal met the delegates in the antechamber, learned about the purpose of their arrival, and informed the Senate and the sovereign. Then he invited the delegation to the Senate Hall. Knocking three times with his baton he asked the senators to give their opinion about the issue under consideration. ${ }^{151}$ That could be done not only by one marshal but also by several at the same time. ${ }^{152}$ Knocking the floor with their

146 'Relacya o stanie politycznym i wojskowym Polski', p. 318.

147 'Opisanie audiencyi xiążąt Ich Mci Repnina z pożegnaniem, Wolkonskiego z powitaniem', fo. 123.

148 Sievers, 'Drugi rozbiór Polski', Cudzoziemcy o Polsce, vol. 2, p. 162.

${ }^{149}$ Rachuba, ‘Udział urzędników', pp. 150-151.

${ }^{150}$ Lileyko, Życie codzienne, p. 153.

${ }^{151}$ Ibid., p. 154.

152 J. Bernoulli, Podróż po Polsce, Cudzoziemcy o Polsce, vol. 2, p. 240. 
batons, the marshals silenced the noisy senators. When the king was going to speak, the marshal asked all senators to come closer to the throne. Then all the marshals knocked their batons on the floor at the same time, and the senior marshal announced that the king wanted to speak. ${ }^{153}$

When the sejm was over, the marshals conducted the ceremony of the farewell to the king, which proceeded in the same way as the greeting. ${ }^{154}$

Marshals and their Insignia in Funeral Ceremonial The ceremonial of breaking the insignia of officials during funerals began to spread in Europe in the fifteenth century. In Central Europe sealmatrixes (dies), swords, staffs of banners and other insignia were broken already during the funeral of the Czech king Ladislas in 1457. ${ }^{155}$ A similar ceremony took place during the funeral of Louis II in 1526. ${ }^{156}$ The batons of Polish marshals were broken for the first time during the funeral of Sigismund the Old. ${ }^{157}$ After the Union of Lublin this ceremony was attended by the marshals of the GDL as well. The baton of the GDL marshal was broken for the first time during the funeral of Stephen Bathory in 1588. ${ }^{158}$ In the funeral procession the marshals carried their batons lowered before the coffin of the ruler (cf. Fig. 7). Sometimes their batons as well as the insignia of other officials were draped in black silk. ${ }^{159}$ In the church the insignia were placed on the altar, at the end of the burial they were broken and cast at the coffin. It must be noted that symbols, specially made for the funeral, were destroyed in this way.

The interpretation of this ceremonial by its witnesses is noteworthy. It is particularly apparent in M.K. Sarbievius' speech during the GDL grand marshal J.S. Sapiega's funeral. ${ }^{160}$ Some of his

153 W. Coxe, Podróż po Polsce, Polska stanisławowska, vol. 1, p. 588.

${ }^{154}$ Lileyko, Życie codzienne, p. 153.

${ }^{155}$ F. Šmahel, 'Smutečni ceremonie a rituály přy pohřbu ćisaře Karla IV', Český časopis historicky, no. 91, čislo 3 (1993), p. 414.

${ }^{156}$ Ibid.

157 A. Grabowski, Ojczyste spomniki, vol. 1 (Cracow, 1845), p. 10.

158 Kronika mieszczanina krakowskiego z lat 1575-1595, ed. H. Barycz (Cracow, 1930), p. 63.

${ }^{159}$ W. Kaczorowski, Koronacje Władystawa IV w roku 1633 (Opole, 1992), p. 28. However, according to M. Radoszewski, seal matrixes were carried not covered. Cf. Radoszewski, Diariusz koronacyjej najjaśniejszego Władysława Zygmunta IV, p. 28.

${ }^{160}$ Laska marszałkowska na pogrzebie Jaśnie Wielmożnego pana Jego Mci P. Jana Stanisława Sapiehi, fos. A-A ${ }^{2}$. 


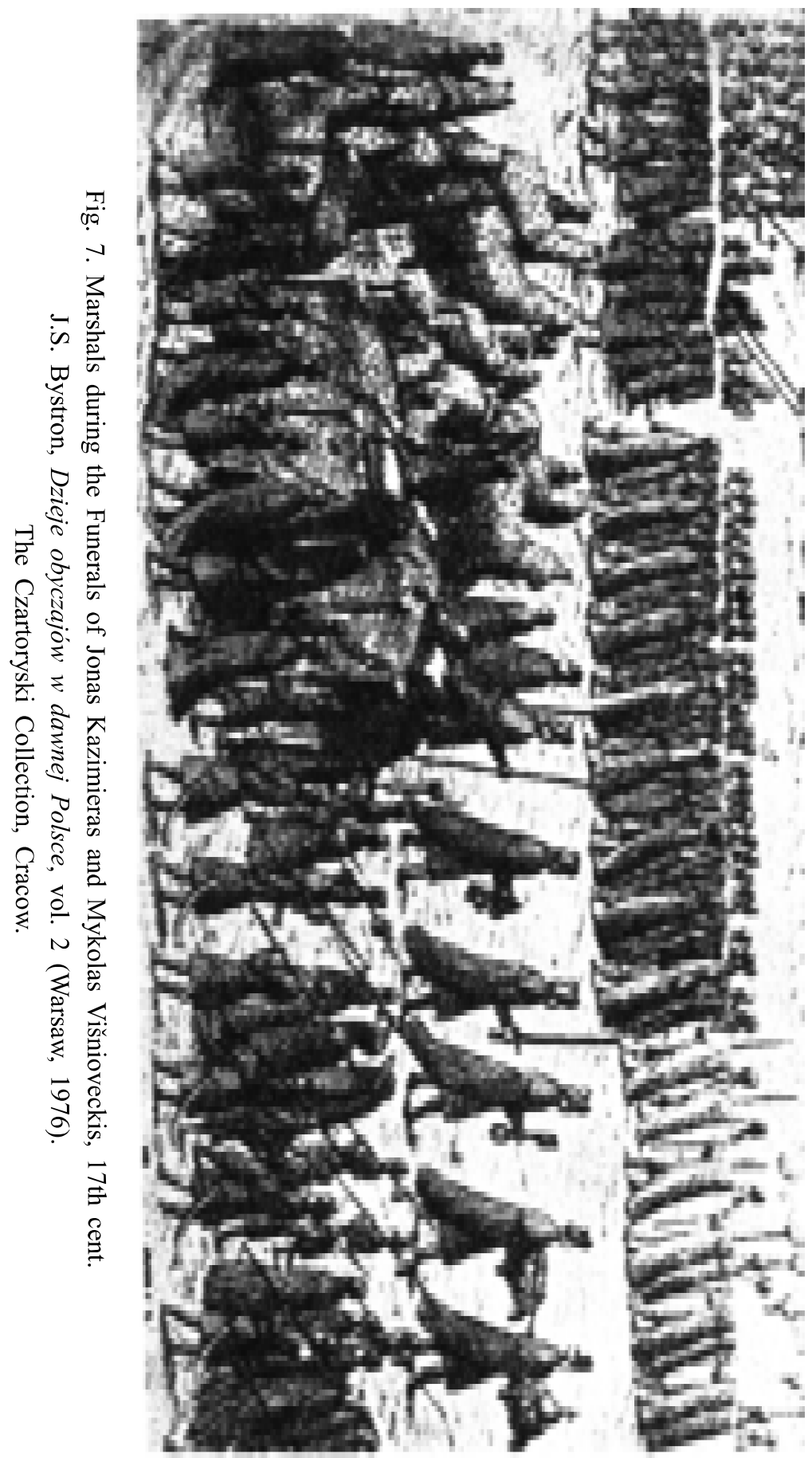


deliberations, in particular the idea that the insignia of the officials were broken because the ruler would find his way to the other world without the help of his officers or because none of the officers would like to accompany him on that journey were probably only rhetorical. However, some of the statements could reflect contemporary attitudes. For example, it was stated that after death the ruler found himself in a different court and among different officials, where the earthly officials and their insignia were meaningless. According to Sarbievius, this ceremony could have been taken from the Catholic Church, since on Good Friday staffs were broken in churches to mark the death of Jesus Christ on the cross. ${ }^{161}$

The Polish investigator W. Kaczorowski argues that breaking insignia symbolised grief for the dead ruler and the rise of the office from the ashes, resembling the rebirth of the phoenix. ${ }^{162}$ Insignia were broken after the fall from the horse of the rider (archimin), who symbolised the king, and his fall symbolised the death of the man, the king. Breaking the symbols of the office meant severing all ties with that ruler and consequently the end of his rule. The new ruler again distributed the insignia to the officials thus accentuating the succession of the royal rule and offices. Meanwhile in hereditary monarchies, such as France, the insignia of officials were not broken. Instead, they were put into the coffin for a short time and were given back to the officials. It was a sort of symbolic interpretation of the phase Le roi est mort, vive le roi!

In the seventeenth century the ceremony of breaking insignia was adopted in the funerals of officials. The earliest information about the funerals of the GDL officials dates back to the first half of the seventeenth century - at that time their ceremonial did not differ from that of the Polish officials. ${ }^{163}$ That the funerals could be

${ }^{161}$ Ibid. There was a custom to mark Christ's death on the cross by casting down religious books with great noise in the church as a token of mourning; cf. U. Borkowska, 'The Funeral Ceremonies of the Polish Kings from the Fourteenth to the Eighteenth Centuries', Journal of Ecclesiastical History, vol.36 (1985), p. 531.

162 Kaczorowski, Koronacje, p. 34; idem, 'Pompa funebris pary królewskiej Zygmunta III Wazy i Konstancji w Krakowie', Wesela, chrzciny i pogrzeby w XVIXVIII wieku, ed. J. Suchojad (Warsaw, 2001), p. 256.

163 The earliest extant funeral descriptions are those of those of the Vilnius castellan Jonušas Radvila in 1620; cf. J. Łukaszewicz, Dzieje kościołów wyznania helweckiego w Litwie, vol. 1 (Poznań, 1842), pp. 160-164; and of the grand hetman of the GDL Kristupas Radvila in 1641; see Jonas Kmita apie etmono Kristupo Radvilos laidotuves 1641 m., transl. E Rimša, Kraštas ir žmonès, ed. J. Jurginis, A. Šidlauskas (Vilnius, 1988), pp. 91-99. 
full of pomp is attested by the wills, containing requests to bury their testators humbly. ${ }^{164}$ The insignia of dead officials were placed in their coffins, in the procession they were borne behind the coffins and at the end of the ceremony, as in the royal funerals, were sometimes broken or cast under the hearse. Images of the insignia could be used for the decoration of the castrum doloris or the whole church.

If in his life the diseased had several posts, the insignia of all his offices were shown during the funeral, thus illustrating his whole career. Thus, in 1751 during the funeral of the grand marshal of the GDL P.K. Sanguška, on the corners of the castrum doloris there were four small stools with crimson velvet cushions decorated with gilt rims and tassels. On one of them was the duke's cap and the order of the White Eagle, on the second two marshal batons, since before becoming grand marshal in 1734 Sanguška was court marshal between 1713 and 1734 . On the third stool there were two buzdygans ${ }^{165}$ as symbols of the captain of two hussar regiments, and on the fourth a cap and a court-sword, symbolising the commander of the court cavalry and infantry. ${ }^{166}$ Insignia were depicted on the outer footings of the castra doloris. The first bore an image of the marshal baton, the second a sword and scales as signs of the marshal court of justice, the third the symbols of the marshal's virtues and the fourth an ermine as the symbol of the duke. The insignia of the deceased were seen in the high altar and in the whole décor of the church. Beneath the crucifix of the pall of the high altar two marshal batons and a ribbon of the order of the White Eagle were shown. ${ }^{167}$ Between the pilasters covered with crimson velvet there were images of torn caps and orders of the duke, and broken batons and buzdygans of the marshals. ${ }^{168}$

The insignia were put on the hearse not only burying the official as such but also parts of his body. ${ }^{169}$ Burying P.K. Sanguška's heart

164 U. Augustyniak, Testamenty ewangelików reformowanych $w$ Wielkim Księstwie Litewskim (Warsaw, 1992), pp. 19, 41, 82.

165 It was sign of a military leader.

${ }^{166}$ Relacya pogrzebowa $w$ przod apparencyi a potym samego aktu ... Sanguszka marszalka wielkiego $W$. X. Lit...

167 Ibid.

168 Ibid.

${ }^{169}$ Burying separate parts of the body, especially the heart, was known in the funeral ceremonial of Western European rulers already in the fourteenth century. In the seventeenth century this practice was adopted in the funerals of some rulers of Poland-Lithuania. Thus, Wladysław Vasa's heart was buried in Vilnius. In the eighteenth century this custom was accepted by noblemen, too. 
the duke's cap and the order of the White Eagle were placed on a cushion to the left of the heart and two marshal batons on the right side. ${ }^{170}$

Polish historians maintain that the insignia of all officials, including those of the marshals, were destroyed at the end of the funeral. However, this is not attested by the descriptions of the funerals of marshals. ${ }^{171}$ Luxurious funerals were not desired by all officials. Wills from the sixteenth to eighteenth centuries contain frequent requests to be buried modestly without any pomp. For example, the grand marshal K.M. Dorohostaiskis expressed such wish in his will in $1615 .{ }^{172}$

So far it is not clear whether after death the marshal baton was returned to the ruler. Meanwhile the seal-matrixes of the chancellors were always returned, ${ }^{173}$ since they were the symbols not only of the chancellors but also of the state. Sometimes, when the chancellor also acted as a hetman, the hetman mace was returned, too. ${ }^{174}$ However, the sources are silent on the return of the marshal baton. Nevertheless, such a probability cannot be discarded outright since the return of the insignia and its handover to the other person signified the succession of that office.

\section{Conclusions}

1. The baton as a part of the insignia of the marshal of the GDL was instituted following the Polish example in the latter half of the sixteenth century. As a symbol it did not change until the Third

170 Relacya pogrzebu serca ... Pawla Karola Sanguszka marszalka wielkiego W. X. Lit...

${ }^{171}$ Doubtless, during the funerals of hetmans and palatines some insignia were broken, others were cast under the hearse.

172 Augustyniak, Testamenty, p. 133.

173 'Zdawanie pieczęci mnieyszej W. X. Lit. Królowi Imci po śmierci J. W. Imci Pana Pawła Sapiehy podkanclerzego W. X. Lit. przez J. W. Imci Pana Leona Sapiehę pisarza na ten czas W. X. Lit. na seymie w Warszawie 1635', Swada polska, cz. p. 228-229; 'Testament Albrychta Stanisława Radziwiłła, kanclerza wielkiego litewskiego, 12 sierpnia 1656 r.' in A.S. Radziwiłł, Memoriale, vol. 4, p. 336; 'Jierzy Liubomirski marszalek wielki i hetman polny oddawa pieczęc wielką po książęciu Radziwille kanclerzu Litewskim', J. Pisarski, Mówca polski, vol. 2 (Kalisz, 1689), pp. 43-46; 'Złożenie pieczęci wielkiey WXLitewskiego przez Michała Korybuta Wiśniowieckiego, 1753', Swada polska, cz. 1, pp. 54-55.

${ }^{174}$ 'Mowa Radzwiłła oddaiąc pieczęc mnieyszą y buławę WXL po Michałe Radziwiłłe oycu swoim', Swada polska, cz. 1, pp. 42-44. 
Partition in 1795. Neither its form nor function underwent any alteration.

2. The ceremonial presentating of the baton was established at the turn of the sixteenth century. It took place in the sejm in the presence of the king. The ceremony consisted of the speech of the former marshal or chancellor, the presentation of the insignia, the oath and acceptance speech of the new marshal, and it ended by kissing the ruler's hand.

3. The main functions of the baton were three. First, borne before the ruler it was a mark of respect to the head of the state. It was carried every time when the sovereign appeared in public from coronation to funeral. Second, knocking the baton to the floor the marshal regulated the procedure of the audience or the sejm session by letting the participants speak or silencing the noisy ones. Third, the baton was sometimes used as an ordinary staff to impose discipline or make way in a crowd.

4. The marshal was responsible for the procedure of any ceremony organised at the state or royal court level. This function was already distinguished in 1504 . However, the place of the marshal in various ceremonies became established at different times. His functions in the royal election and coronation were fixed definitely during the royal election after the death of Sigismund August in 1752. Batons had been borne before the ruler since the late sixteenth century. The functions of the marshals in the reception of envoys were established finally in the late sixteenth and early seventeenth centuries and in the ceremonial of the sejm after the Union of Lublin in the latter half of the sixteenth century.

5. As a symbol of the office of marshal the baton could be depicted in the official's coat of arms, seals, portraits and used in the ceremonial of his funeral.

\section{Translation: Alfonsas Laučka}

\section{Author Details}

Dr Gitana Zujiene is a junior researcher in the Department of the History of the Grand Duchy of Lithuania, the Lithuanian Institute of History. Her research interest is ceremonial and insignia in Lithuanian public life in the 13th -18 th centuries.

Address: Department of the History of the GDL, Lithuanian Institute of History, Kražiu 5, LT-01108 Vilnius, Lithuania

Email: zgitana@centras.lt 
LDK MARŠALŲ INSIGNIJOS IR JŲ VIETA CEREMONIALE XVI-XVIII A.

Santrauka

\section{GITANA ZUJIENE}

Straipsnyje nagrinejjama vieno iš aukščiausių valstybès pareigūno - maršalo, tarp daugybès savo funkcijų atsakingo ir už ceremonialo organizavimą, insignijos maršalo lazdos - raida ir vieta valstybiniame bei dvaro ceremoniale. Aptariama jos kilmè ir išvaizda. Rekonstruojama šios insignijos įteikimo pareigūnui ceremonija. Maršalo lazdos vieta ceremoniale parodoma aptariant paties maršalo vietą ir funkcijas valdovo elekcijos ir karūnacijos, dvaro, pasiuntinių prièmimo ir seimo ceremonijų metu. Tai, jog maršalas atsakingas už kiekvieno ceremonialo organizavimą, buvo patvirtinta dar $1504 \mathrm{~m}$. Tačiau įvairiose ceremonijose Lietuvos maršalų vieta nusistovejjo skirtingu laiku. Tam įtakos turejjo ir 1569 m. sudaryta Liublino unija su Lenkija, pakreipusi kai kurių funkcijų raidą kita linkme, o dalį funkcijų apribojusi. Maršalo funkcijos valdovo elekcijos ir karūnacijos iškilmėse galutinai susiformavo vykstant valdovo rinkimams po Žygimanto Augusto mirties 1572 m. Lietuvos maršalai kartu su Lenkijos maršalais rūpinosi tvarka elekciniame lauke, pranešdavo apie naujojo valdovo išrinkimą. Jie organizuodavo karūnacijos ceremoniją ir jos metu procesijoje nešdavo prieš valdovą savo insignijas. Tuo tarpu iki Liublino unijos Lietuvos žemės maršalas kartu su Vilniaus vyskupu lygiomis teisemis dalyvaudavo didžiojo kunigaikščio karūnacijos ceremoniale ir itteikdavo jam kalaviją.

Pasiuntinių prièmimo ceremoniale maršalų funkcijos baigė formuotis XVI a. pabaigoje - XVII a. pradžioje. Lietuvos maršalai buvo atsakingi už pasiuntinių prièmimą Lietuvoje ir už Rusijos pasiuntinių prièmimą Lenkijoje (santykiai su Rusija po Liublino unijos priklausė Lietuvos pareigūnams). Jie organizuodavo iškilmingą pasiuntinio įvažiavimą i miestą, suderindavo audiencijos pas valdovą laiką, organizuodavo pati prièmima, jos metu sutikdavo pasiuntini prie salès durų ir palydèdavo ị vidų, vadovaudavo pačiai audiencijai.

Seimo ceremoniale Lietuvos maršalų funkcijos buvo nustatytos taip pat po Liublino unijos, XVI a. antrojoje pusejje. Jie savo pareigas eidavo seimui vykstant Lietuvos Didžiosios Kunigaikštystės teritorijoje, Gardine. Maršalai vadovaudavo Senato posèdžiams, organizuodavo Atstovų rūmų pasisveikinimo su valdovu ceremoniją, Atstovų rūmų delegacijų i Senatą prièmimą, seimo pabaigoje - atsisveikinimo su valdovu iškilmes. Seimui vykstant Lenkijoje jie galejjo pavaduoti Lenkijos maršalus bei vadovauti Lietuvos atstovų prièmimui seime.

Lazda Lietuvos Didžiosios Kunigaikštystès maršalo insignija tapo XVI a. II puseje. Didieji ir dvaro maršalai naudojo dviejų tipų lazdas. Seime - paprastas ilgas balto medžio lazdas. Iškilmių metu - juodmedžio, puoštas sidabriniais, paauksuotais apkaustais, brangakmeniais. Šios lazdos kaip simboliai išliko nepakitę per visą laikotarpi iki valstybès žlugimo $1795 \mathrm{~m}$. Nesikeitè nei jų formos, nei funkcijos.

Insignijos iteikimo ceremonialas susiformavo XVI a. pabaigoje - XVII a. pradžioje. Ceremonija vykdavo seime, dalyvaujant valdovui. Ją sudarè iškilminga ankstesniojo maršalo arba kanclerio kalba, insignijos iteikimas, naujojo maršalo priesaika ir padèkos kalba. Ceremonijos pabaigoje naujasis maršalas bučiuodavo karaliui ranką ir pradėdavo eiti savo pareigas. Pagrindinès lazdos funkcijos buvo trys. Pirma - nešama prieš valdovą ji simbolizavo valdovui rodomą pagarbą. Nešdavo 
maršalas ją visada valdovui pasirodant viešumoje, pradedant karūnacija, baigiant laidotuvemis. Jos laužymas valdovo laidotuvių metu išreiškẻ gedulą ir ryšių nutraukimą su mirusiuoju.

Maršalo lazda atliko ir „,balsų valdovès“, kaip ją vadino amžininkai, funkciją. Stuksendamas ja i grindis maršalas reguliuodavo kalbètojus pasiuntinių audiencijos arba seimo metu - suteikdavo žodi arba tildydavo įsiaudrinusius kalbetojus. Be to, maršalo insignija kartais atlikdavo paprastos lazdos funkciją, prireikus sudrausminti išsišokèli arba praskinti kelią minioje.

Kaip maršalo pareigybès simbolis lazda galèjo būti vaizduojama jo herbe antspauduose, portretuose, naudota pareigūno laidotuviu ceremoniale. 